\title{
Bush, the Media \& the New American Way
}

\author{
Louise F. Montgomery \\ University of Arkansas, Fayetteville, Arkansas, USA
}

\author{
Imontgom@uark.edu
}

\begin{abstract}
The run- up to a full-scale U.S. military attack on Iraq - "shock and awe" -- provided an unusual and ideal test the effectiveness of a parsimonious content analysis methodology designed to determine when a national leader made or would make a decision to go to war. As W. Ben Hunt's work that is the model for this study anticipated, editorials in The Wall Street Journal clearly ramped up war fever with not only the number of "get to it, George" editorials but also with the language. Critical editorials advised/urged/demanded Bush to get on with the second phase of the long-planned remaking of the Middle East -- taking out Saddam Hussein. The paper links several aspects of post-Cold War, postmodern American life -- low levels of knowledge, use of poll data throughout society, declining news consumption and others -- to paint a picture of a newly vulnerable society, one willing - polls would indicate - to listen to and follow clear, perhaps simplistic, policies even to the point of a pre-emptive strike on a small nation that many could not locate on a map.
\end{abstract}

Keywords : The Wall Street Journal, Newspapers, Media, public opinion, war, W. Ben Hunt, Iraq, President George W. Bush, United States

\section{Introduction}

George Bush's presidency has been defined by military action, first in Afghanistan, then in the run-up to attacking Iraq. His presidency has also been distinguished by the scant number of live press conferences (two during prime time in two years); secrecy, misstatements and threats made by Bush and by cabinet members, particularly Secretary of Defense Donald Rumsfeld (Rumsfeld remarks). New York press tagged journalists' docility at a March 2003, "a political catastrophe" and "a mini-Alamo for American journalism" (Gladstone, 2003).

After the Sept. 11, 2001, attacks on the Pentagon and World Trade Towers in Washington and New York, unprecedented limitations placed on civil liberties met with little resistance from a fearful public. As Bush's verbal attacks on Iraq escalated through 2002 and into 2003 and military might massed on Iraqi borders, Bush became known around the world for strong-arming other nations' leaders, with a bucket of million dollar bills, for support despite worldwide popular resistance and for his unilateral abandonment of long-held treaties and allies. While Bush and the United States are despised by large majorities in most of the Arab world, including nations that are official allies of the United States (Moore, 2002), Bush's poll ratings with the American public inched upward even as American troops forged toward Iraq (Gallup, March 2003; see Figure 1). Even more nuanced polls such as the March 7 ,

Material published as part of these proceedings, either on-line or in print, is copyrighted by Informing Science. Permission to make digital or paper copy of part or all of these works for personal or classroom use is granted without fee provided that the copies are not made or distributed for profit or commercial advantage AND that copies 1) bear this notice in full and 2) give the full citation on the first page. It is permissible to abstract these works so long as credit is given. To copy in all other cases or to republish or to post on a server or to redistribute to lists requires specific permission from the publisher at Publisher@InformingScience.org
2003, CBS poll, showed that a majority of Americans polled supported Bush (CBS, ). Bush has won Gallup's "most admired man" award, announced in December, for the second year in a row (Carroll, 2002). At the same time Bush maintained poll ratings rivaling the most popular American presidents (Figure 1), he remained seemingly immune to economic and other domes- 
tic problems and to political opposition. Many Democrats (21 in the Senate, 126 in the House), some explaining that the nation should be united on a war resolution, voted to authorize use of force against Iraq (Senate legislative events calendar, 2002). However, as the United States increased bombings in the U.S.-U.K.- designated "no-fly zones" (Graham-Brown, 2001) in Iraq and brought troop strength in surrounding countries to more than 250,000, Democrats unified sufficiently in early 2003 to filibuster and block nomination of a nominee to the federal bench. But most Democrats' statements remained cautious on Iraq, even as millions of Americans joined anti-war protestors around the world. Criticism of Bush in the media has likewise been muted (Sperling, 2002; Kuttner, 2002) not only on Bush's war efforts but on curbs on domestic freedoms that violate some of the hallmarks of American life (ACLU, 2003). Perhaps because they can't find what they are looking for in U.S. media, Americans have turned toward non-U.S. sources for news in increasing numbers since Sept. 11, 2001 (Campbell, 2001). Choosing a non-U.S. news source could be triggered by a number of reasons, but one is certainly perceived short-

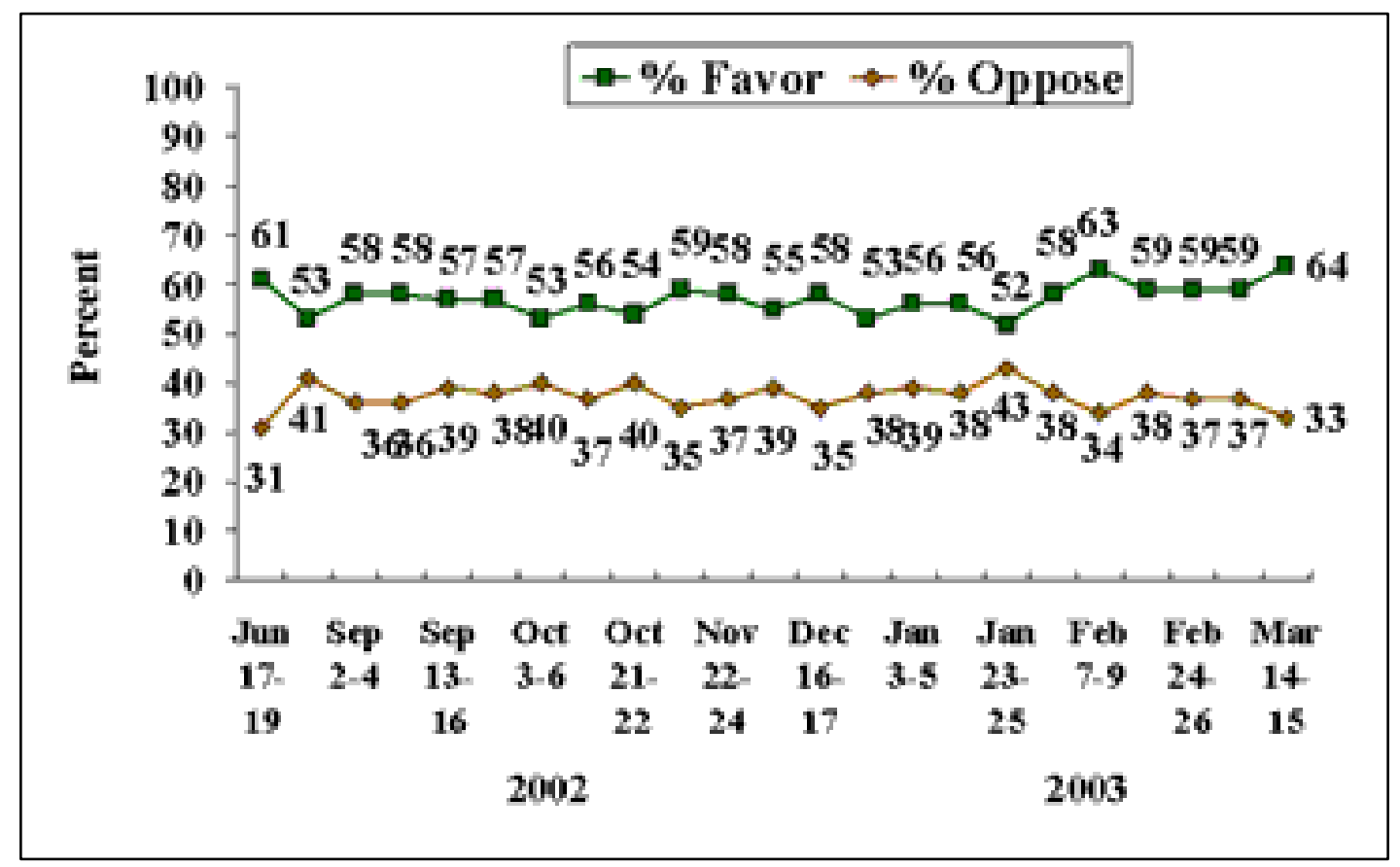

Figure 1: U.S. Support for a U.S. attack on Iraq: March 2003

(Jones, 2003; Copyright 2003, the Gallup Organization, all rights reserved. Reprinted with permission.)

comings of all U.S. media, but partic ularly the most-popular news source, television news (FAIR, 2003). An Australian critic called American TV "jingoistic, sugar-coated, superficial” and likewise faulted U.S. newspapers (Sydney Herald; Campbell).

\section{Purpose of This Research}

The main goal of the paper is to determine whether editorials in the nation's second-highest circulation newspaper, the business-oriented Wall Street Journal, anticipate the commencement of war in Iraq, as W. Ben Hunt's pioneering (if little acclaimed) work, Getting to War: Predicting International Conflict with Mass Media Indicator, found in the 1991 attack on Iraq (Hunt, 1997). Hunt applied his method (described later in this paper) to the Desert Storm campaign as well as other conflicts throughout the $20^{\text {th }}$ century. Following Hunt's caveat, this work isn't suggesting that reading a nation's elite newspapers is all one has to do to know which way the political conflict wind blows but rather to bring about "greater appreciation of the regular and predictable aspects of the internal behaviors of the parts (of the system) toward building a general theory. Nor does this research suggest that editorials in a newspaper might cause a war; the expectation is that elite newspapers telegraph the plans of political elites. This paper 
links several facets of American life to the runup to war in Iraq -- the news media, the Bush presidential style and team and the low level of knowledge of Americans. Poll data ranking President Bush as among the top-ranked presidents in history are plotted against the position he and the United States hold in the rest of the world. The expectation is that the state of intellectual life in the United States, the nature of the media and the composition and behavior of the presidential team all contribute to the likelihood that Journal editorials, both by quantity and by tone, will anticipate "getting to war."

This paper reviews the interactions of media and public opinion, and foreign policy, linking poll data and newspaper circulation figures to the well-known (and embarrassing) phenomenon of Americans' low level of knowledge of public affairs, geography, and history. With that backdrop, it uses content analysis of editorials in The Wall Street Journal to determine their relationship with world events. In the case of Iraq, which the United States bombed almost continuously from 1991 forward, the lack of a clear-cut starting point to "war" or "conflict" could present special problems.

\section{Background}

Media scholars have for decades attempted to understand the three-way relationship involved in public opinion, material disseminated in the mass media and governmental policies and actions. In one major group of studies, several scholars examined government systems, press freedom and newspapers, the major medium of the first half of the $20^{\text {th }}$ century (Siebert, 1956). Siebert's study published in 1952 on the development of press freedom in England rested on the observation that leaders' willingness to permit freedom of the press was directly related to pressures the nation experienced externally and internally (including public reaction). In the 1950s, in the first mammoth computer-assisted content analysis, Ithiel de Sola Pool, Harold D. Lasswell and Daniel Lerner analyzed elite newspapers around the world. In two books, the team empirically linked what was published in prestige newspapers to social changes and to political elites (de Sola Pool, 1951, 1952).

The de Sola Pool 1951 work noted: "(Elite newspaper opinion) is always in some way tied to the go vernment, the degree of intimacy being a function of the politicization of the particular elite," and the newspapers provided an opportunity to detect "semiofficial expressions of elite opinion." The authors noted, citing Speier, that public opinion became an influence on foreign policy in the $20^{\text {th }}$ century (1970). Prestige newspapers, they said, represent the government point of view, especially on foreign policy (p. 222). In another major body of work, the title of Deutsch's 1963 study of the mediagovernment relationship - The Nerves of Government - telegraphed his assessment of the role played by a nation's communication system. Deutsch emphasized the necessity that national leaders in democracies build public support to spend the political and financial capital for armed conflict.

...Democracies will find it necessary, and even dictatorships find it expedient, to reduce or dispel this apathy by confronting their populations with the image of a single, sharply defined enemy and a single, clear-cut conflict...It should be possible to say whether the amount of attention given to a specific conflict area or to the image of a particular 'enemy' country is reaching the danger point....it should be possible to construct an "early warning system," in regard to the mass-communication aspects of interstate conflicts. (Deutsch, 1957, cited in Hunt, 1997)

Hunt complemented the Deutsch's ideas with game theory and ma thematical proofs, but after testing his theories and methods with long-term content analysis of newspapers from around the world, he determined that the simple and elegant method of looking at editorials, which he found to be more revealing of an administration's plans than diplomatic communication, predicted the onset of war in almost all cases across time. 


\section{The man in the street and the men in the White House}

Whether the "man in the street" influences foreign policy and whether such influence is desirable has been the focus of numerous studies, many of them related to polling. Anyone reading or viewing modern mass media can attest to the ir ubiquity. Polling has been used to test public reaction to women's wearing bathing suits in beauty contests (Holsti, 1996) but answering pollsters questions, even if you don't know anything about the topic, has become one way to participate in political life. Voters knew so little about candidates in a school election in California that they relied on party labels (Schaffner and Streb, 2002). Indeed, in one poll in the runup to the U.S. attack on Iraq, Americans were asked whether the U.S. Congress should declare war. Sixty-two percent said yes; a follow-up asked against whom war should be declared. Sixty-one percent didn't know, but two percent added, "No one; just declare war" (Robertson, 2003). Robertson wrote that pollsters ask Americans questions that they couldn't answer: Is Osama bin Laden alive or dead? Would you kill him, given the opportunity? How long will the war last? (This was for the Afghanistan war.) Making data of dubious value meaningful is a challenge for journalists who find meaning in polls that have no meaning because of the margin of error. Robertson (2003) quoted CNN's Garrick Utley's handling of the poll in which people wanted to go to war but didn't know the name of an enemy: "That uncertainty gives President bush flexibility and time to determine what kind of a war he intends to wage."

American's lack of knowledge extends across topics and even includes illusions about what they do know. People who couldn't define "molecule" or display knowledge of other basic science facts told pollsters that they understood science (National Science Board, 2003). Seniors at Ivy League colleges can't distinguish between statements by Karl Marx and the Founding Fathers of the United States ("Students Flunk U.S. History Test”). Nearly 60 percent of City University of New York - and many other schools had similar figures -- students would be denied citizens hip because they could not correctly answer at least 7 of 10 basic American history questions as required of immigrants seeking U.S. citize nship (Center for Excellence, 2000). More Americans correctly located the Marquesas Islands as the site of a Survivor series than could find New Jersey, and young people old enough to be sent to war in Iraq can't fid it on a map (Global Goofs, 2002).. The Columbia Law survey results demonstrated that "little more than half of college seniors know general information about American democracy and the Constitution," and most "do not know specifics about major wars the United States participated in" (Passantio, 2002). Nearly one-third of Americans (29 percent) think the Constitution guarantees a job (National council on Economic Education).. Forty-two percent think it guarantees health care. The pile- up could continue ad infinitum, but the pint is made: On almost any topic, Americans of all ages know little although they think they are knowledgeable. On many tests, American score at the bottom of third-world countries; for example, on the annual National Geographic exam (Global Goofs, 2002), Americans scored higher than only one nation, Mexico.

"If our young people can't find places on a map and lack awareness of current events, how can they understand the world's cultural, economic and natural resource issues that confront us?" asked John Fahey, president of the National Geographic Society (Fahey, 2002).

Americans attention to newspapers and television has dropped dramatically in the last few decades likewise have abandoned TV news programs as show-business values replaced jour nalistic values and TV executives stifled investigative reporting. As Murdoch-owned Fox news challenged the traditional three networks for dominance and the blur between news and entertainment, a respected news reporter Peter Boyer expressed his thoughts in Who Killed CBS - The Undoing of America's Number One News Network (1988). The network news audience plummeted from 60 percent of Americans in the mid 1990s to 30 percent in 2002, with only 20 percent of college graduates younger than 50 watching TV news (Patterson, 2002). College students' media usage has shifted to the unedited internet (Figure 2), with newspaper use among students in Whitaker's sample dropping below all other media. Similar disenchantment 
with "news-lite" in the United Kingdom led to almost a 50 percent drop in the audience of Tonight with Trevor McDonald and to a columnist's dubbing TV "an idiot's lantern" (Cox, 2002).

Newspaper readership declined from an average of 51 percent of Americans 18 years and older in 1997 to 46 percent in 2000, with declines in all age group. Weekday newspaper dropped from 76 percent to 68 percent, and TV news viewing dropped from 88 percent to 80 percent in the same three-year time span. The American audience's limited taste for news - and the gap between journalists and "ordinary Americans -- is demonstrated by a newspaper columnist's experience on the eve of Bush's March 17 press conference in which he delivered the first-time declaration-of-war ultimatum on TV. The caller to the Akron Beacon-Journal wanted to know the age and marital status of the man on Wheel of Fortune (Heldenfels, 2003).

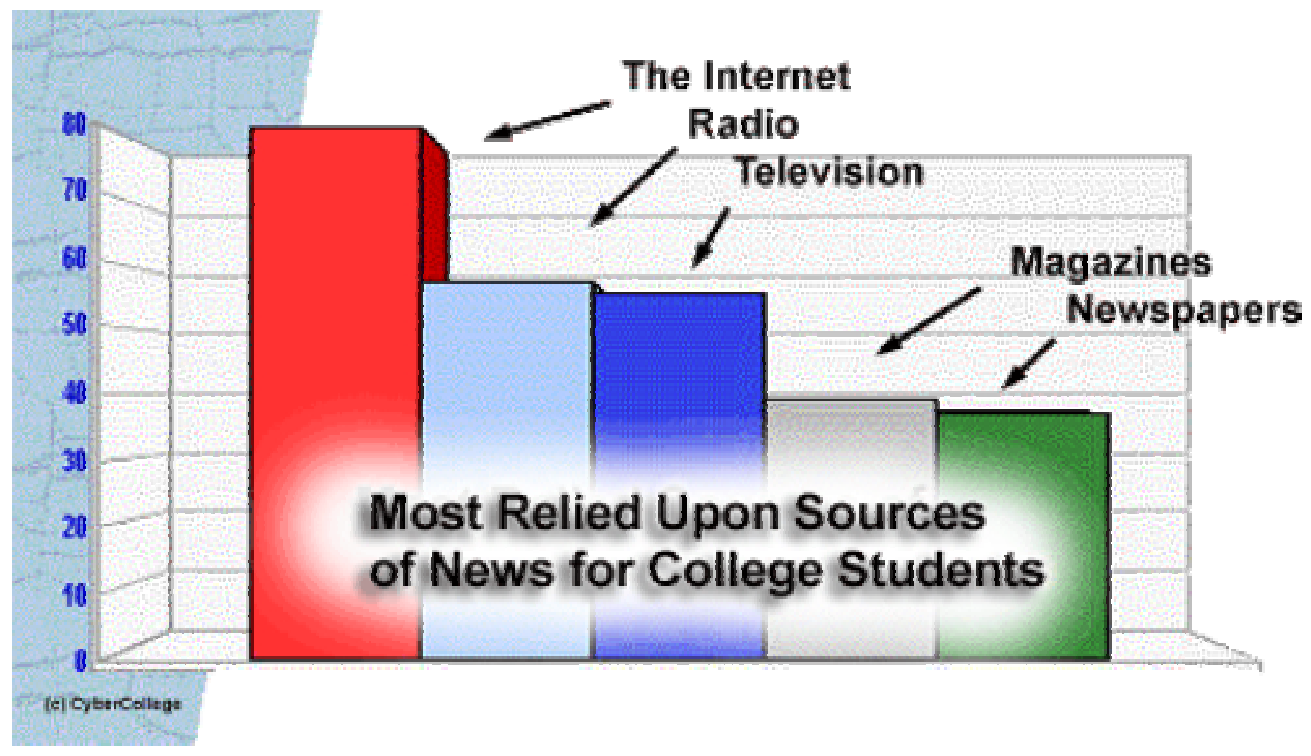

Figure 2: Americans Students' Sources of News, January 2003

(Whitaker, 2003)

Pollsters have long known that Americans' knowledge levels are low, but they want the data anyway. Holsti (1996) noted that poorly informed Americans provides increasing opportunities for public participation in foreign policy, but other scholars question their merit. Authors of three important postWorld War II studies of public opinion and foreign policy examined the major polls of the war years and reacted with "a distinctly skeptical view of the man in the street" and his contributions to foreign policy conduct (Holsti, 19, citing Bailey (1948), Markel (1949), and Almond (1950). The authors feared that ill-informed, emotional Americans would drive foreign policy in a direction they considered undesirable (toward isolationism). During the same period, however, some administrations made good use of public opinion to gain approval of the Marshall Plan, NATO and the Limited Test Ban Treaty (Holsti, 211212). Post-Vietnam research also challenged previously held views that public opinion was volatile, structureless, and without significant impact on policymaking (Holsti, 20). Despite that realization, politicians largely ignore citizens' viewpoint on public issues such as Social Security, resorting instead to vague claims in the people's names (Cook, Barabas, and Page, 2002) that were sometimes misleading or inaccurate. Claims in Congressional testimony that the public viewed Social Security as "bankrupt" and that privatization is the solution, for example, were not complemented with contrary findings in poll archives. The authors called such misuse "disturbing" and warned of its negative impact on "democratic responsiveness."

Another recurring theme in discussions of media, public opinion, on the one hand, and political leaders and foreign policy, including war, on the other, questions whether inaccurate or misleading "news" and 
disinformation render public opinion meaningless. Lippmann (1920) complained that "the manufacture of consent" by an "unregulated private enterprise" - the press - amounted to a crisis of western civilization, a crisis of journalism. He and Charles Merz, a colleague at The New Republic, found that The New York Times' coverage of he Russian Revolution was "inadequate and misleading." They said news about Russia came about by men seeing what they wanted to see, with the effect of "almost always misleading" (Lippmann and Merz 1920, 42).

Another concern that has taken front court in the post-modern era concerns official government misinformation (also called disinformation). However, official disinformation -- lying -- is nothing new in public life. Though the specifics differ, a host of modern examples suggest that disinformation is or has become standard procedure. At the end of the $19^{\text {th }}$ century, the alleged attack on the battleship Maine became an infamous media event as well as the pretext for President McKinley's intervening in the $\mathrm{Cu}-$ ban war for independence from Spain (Spanish-American War). FDR's "optimistic public expressions" on Russia helped hold together the Allied World War II. Lyndon Johnson's account of an attack on American ships in the Gulf of Tonkin led to Congressional approval for widening the war against Vietnam (Holsti, 1996). President George H.W. Bush's relationship to the Iran-contra scandal escaped the scrutiny of the U.S. prosecutor investigating Iran-Contra because the prosecutor focused on criminal prosecution. "The main charges against Bush are not of criminal misconduct, but of distorting the truth a political sin, perhaps, but not a criminal offense" (McManus, 1992). With Nixon's Watergate shenanigans and Clinton's zipper problems, the list includes all presidents in the last half of the $20^{\text {th }}$ century except Nobel Prize winner Jimmy Carter. Indeed, disinformation seems to be the rule rather than the exception.

\section{Bush administration secrecy and manipulation}

George W. Bush's approach to foreign relations can be seen as the behavior of a self-confident but folksy Yale fraternity president (Delta Kappa Epsilon), a baseball team owner and a Texan given to malapropos (Among the many Bushsites, If he makes it, we're doomed). At about the same time Bill Clinton found a National Guard slot through the help of a political friend, Bush signed up for the Guard, going ahead of about 500 on the list, but left no official paper trail of completing his three-year assignment (Robinson, 2000). He is viewed by some critics as a front man for plans and ideas crafted decades ago by hawkish members of his cabinet who also served his father (Lewis, 2002). While proclaiming openness, the president practices secrecy. Presidential press secretary Ari Fleischer declared: "The bottom line remains the president is dedicated to an open government, a responsive government, while he fully exercises the authority of the executive branch." But an expert on government secrecy, Alan Brinkley, a Columbia University historian, said the Bush administration has "taken (secrecy) to a new level." The Bush administration's instinct is to release nothing, Brinkley said, adding "They are just worried about what's in there that they don't know about" (Clymer, 2003). Among the successes was Vice President Dick Cheney's ability to keep records of his energy task force secret. Even before Sept. 11, Attorney General John Ashcroft ordered government officials to reject requests when legally possible under the Freedom of Information Act. Classification of documents as secret edged up 18 percent in Bush's first year. Some 68,000 Reagan-era records were closed Nov. 1, 2001 (Taiara, 2003). In the legal area, the secrecy was even more intense. Since the Sept. 11 attacks, immigration officials have exercises a rare degree of secrecy about individuals who are arrested and detained. Immigration hearings for hundreds of people caught in sweeps after the bombings have been closed to relatives, the news media and the public. Names and details of people INS detained were kept secret; in December, the Associated Press was able to get the number of people arrested and released from the Justice Department. Bush the president has behaved in the same secret manner as Bush the governor (Clymer, 2003).

Bush administration secrecy has sparked little public debate but has generated bipartisan congressional complaints. Democrat Sen. Patrick J. Leahy, first elected in 1974, said, "Since I've been here, I have 
never known an administration that is more difficult to get information from." Republican Sen. Charles E. Grassley, chair of the Senate Finance Committee, said things were getting worse, and "it seems like in the last month or two, I've been running into more and more stonewalls." Legal scholars have objected to immigration and courtroom restrictions.

In March 2003, the Senate Foreign Relations Committee docket called for a hearing on "post-War Iraq." The White House sent no one to testify. Senator Chuck Hagel, the Republican from Nebraska who chairs the committee, reacted: "We all pushed to give us some sense of this. No answers. The administration chose not to have witnesses today. No answers. I think the president was asked in his news conference the other night. No answers. And I think the best that they have come up with is, 'Well, you'll know about it when we bring up the supplemental appropriation.' I don't think that's a good way to do this" (Norris, 2003). The senators had read in The Wall Street Journal, they said, that the Agency for International Development was taking bids on rebuilding Iraq from a handful of companies, including Halliburton, the firm Cheney's headed before he became vice president and from which his 2001 financial disclosure statement said he draws up to \$1 million a year (Bryce, 2003).

Sen. Christopher Dodd, ranking Democrat on the committee, reacted angrily to the White House failure to testify:

"I find that terribly disturbing. There's an arrogance to that. That is, we've seen evidence in allied reaction to the effort in Iraq, and it's now showing up here, and I don't think that's going to be very helpful. That's going to make the job of winning my support for those kind(s) of efforts a lot more difficult in the coming months." (Norris)

The House has even greater difficulties, given the two-year election cycle.

(The Bush administration's) attitude toward Congress is contemptuous; it tells legislators only what it is forced to, and takes Congress into consideration only when there is no other choice. Other administrations have played loose with the truth, especially when it came to obtaining the power to wage war, but the Bush administration does a striking amount of it. And it's an administration that plays rough. (Drew, 2002)

At the same time, journalists are manipulated openly. Bob Woodward of Watergate fame - and perhaps infamy for his latest effort, Bush at War, has a key to the White House (Confessore, 2002). Woodward's colleague at the Washington Post, Dana Milbank, suffers insults, calls to his editors and other marks of being an outsider or, perhaps, a journalist. The few press conferences Bush sets (his second live press conference occurred as his "shock and awe" phase of the Iraqi attack was about to start in March 2003) are scripted, with favored journalists or plants tossing softballs to the president. Burmese journalist exiled in Thailand gave American journalists a tongue-lashing: "America's journalists have failed in their duty to ask questions about the consequences of war in Iraq and to report on its growing worldwide opposition,” wrote Aung Zaw (2003). “...America's mainstream media has been far from encouraging, as many journalists seem dangerously ignorant of their public duty. Since Washington started selling the idea of war on Iraq, mainstream media outlets in the US have been filled with 'objective' reporting — inflated by the ongoing rhetoric from officials." Reporters without Borders pleaded unsuccessfully for the release of Sami Al-Haj, a Sudanese cameraman for the Qatar television station Al-Jazeera who was swept up with some 600 other people in Afghanistan and held at The U.S. military compound in Cuba, Guantanamo (Al-Jazeera, 2002).

\section{Bush's team}

Bush's actions are best understood within the framework of the team he assembled as advisers and cabinet members. Curiously, the major hawks were trained by a Democrat, the late Henry "Scoop" Jackson of Washington state. Though he died in 1983, Jackson, more than any other person, may be responsible for the Bush administration's bellicose showdown with Iraq and its muscular new doctrine of pre- 
emption. “Today's grey eminences behind the 'war on terror' were once young apprentices under (Dorothy Fosdick’s) supervision” (Borger). Fosdick was Jackson's foreign policy adviser for 28 years.

Paul Wolfowitz and Doug Feith, the two leading strategists in the Bush-Cheney defense department, and Richard Perle, an influential Pentagon adviser though not an elected or appointed official, are former Democrats who worked for Jackson in the 1970s; all three considered Jackson as their me ntor. Perle claims to be a registered Democrat, and Wolfowitz has described himself as a "Scoop Jackson Republican" (Borger, 2002). Another Jackson protégée, Elliott Abrams, is in charge of White House policy in the Middle East. Abrams, who was convicted of misleading Congress about the Iran-contra affair, remains committed to Jackson's argument favoring use of American power with principled support of human rights. Another Jackson protégée, Frank Gaffney, runs the Center for Security Policy, a rightwing think tank that has served as an incubator for the emerging themes of Bush foreign policy since Sept. 11: the assertive use of military power, an aggressive pre-emptive approach to emerging threats, and uncompromising support for the Likud party and its policies in Israel (Borger, 2002).

The names, like many of the policies, can be traced back to the Reagan White House. Several have argued for years that Hussein should be removed from power. They have sought to push the younger Bush farther into the plan they devised for the Reagan administration than the first Bush would accept. Their influence is apparent in the September 2002 Bush document, "National Security Strategy of the United States." It is similar to one published in 2000, "Rebuilding America's Defenses: Strategy, Forces and Resources for a New Century," a document in the works since 1997. Several member of the Bush cabinet, listed in the report, helped create the document (Rebuilding, 2000) (http://www.newamericancentury.org/RebuildingAmericasDefenses.pdf). Numerous writers have made connections between several Bush cabinet and sub-cabinet members and Likud, the Zionist party devoted to establishing Israeli dominance in the Middle East (Vest, 2001; Alterman, 2003; ), Bush's modus operandi can be seen in a close look at the secrecy issue.

Just as many of the younger Bush's cabinet were recycled from the first President Bush's staff, their policies differ only slightly in relation to war. The elder Bush moved away from the Cold War's emphasis on containment rather than war became more comfortable with the idea of governing through the use of force (Knight). Knight wrote: 'President Bush the Younger's new strategy takes us further down the road toward normalizing war as an instrument of choice for achieving valued ends. For an official document of the U.S. government (in accordance with the Goldwater - Nichols Defense Department Reorganization Act of 1986), the Bush National Security Strategy of 2002 is disturbingly insubstantial, ideological, and, at times, disingenuous. All together, it betrays a remarkably casual attitude toward matters of grave concern to Americans and many people around the globe." The Strategy document reiterates the strategic goal that Wolfowitz and Cheney articulated in the 1992 Defense Planning Guidance: "Our forces will be strong enough to dissuade potential adversaries from pursuing a military build-up in hopes of surpassing, or equaling, the power of the United States" (p. 30 in Strategy document).

The administration, according to Knight-Ridder reporters Warren P. Strobel, Jonathan S. Landay, and John Walcott, put "very strong pressure" on Pentagon analysts "to cook the intelligence books" and come up with information to corroborate the Bush administration's charges that Iraq poses a grave and imminent threat to the United States (Strobel). Unnamed federal officials charged that the administration squelched dissenting views and that intelligence analysts were under intense pressure to produce reports supporting the White House's arguments demonizing Saddam Hussein.

\section{Propaganda and "Disinformation"}

Observers around the globe have witnessed the Bush administration's ever-changing, yet constant, rhetorical runup to war. Canadian speechwriter David Frum is credited with originating the phrase that generated perhaps the most controversy of any of Bush's speeches - the infamous "axis of evil" moniker 
applied to Iraq, Iran and North Korea. Before Frum resigned to publish the first insider account of the Bush White House, he contributed the phrase "axis of hatred" to Bush's first State of the Union address. The phrase became the "axis of evil" in Bush's 2002 State of the Union address and became identified with Bush's rhetorical excesses and well as with his rejuvenated public image after Sept. 11 (Frum, 2003). Frum's story of how the phrase morphed from "axis of hatred" makes clear how important language is to the Bush administration. Frum applied his phrase only to Iraq, but National Security Adviser Condoleeza Rice argued that Iran should be included; then the administration decided it didn't want to appear to be targeting only Muslim nations, so North Korea was added. "Hatred" became "evil" to keep the theological tone that Bush had adopted since Sept. 11. Frum and conservative Brent Bozell (Bozell) likened the controversy over the phrase to media reaction to Reagan's naming the Soviet Union the "evil empire." Bozell complained about the media's "evil-dismissing trend," and wrote that his Media Research Center analysts found only 5 references (14 percent) to the evil nations in all 37 evening news stories on $\mathrm{ABC}, \mathrm{CBS}$ and $\mathrm{NBC}$ discussing the "axis of evil" from the day after the State of the Union speech through Feb. 19.

The administration's willingness to present dubious evidence in its attempt to prove that Saddam Hussein violated U.N. resolutions brought rebuke at the United Nations and in the Congress. In March 2003, the U.S. Senate Foreign Relations Committee demanded investigation of documents submitted as proof that Iraq had continued its weapons program. Mohammed El Baradei, head of the International Atomic Energy Agency, told the U.N. Security Council that the documents were forgeries ("Top Democrats..."). In another fracas, National Public Radio reported that Republican Foreign Relations Committee Chair Sen. Richard Lugar was "startled" to learn from the Wall Street Journal that the administration had asked selected companies, including Halliburton, to bid on rebuilding post-war Iraq. Yet the administration declined to send anyone from the White House to testify at the committee's hearings on post-war Iraq. Democrat committee member Sen. Christopher Dodd reacted: "There's an arrogance to (White House behavior). That is, we've seen evidence in allied reaction to the effort in Iraq, and it's now showing up here, and I don't think that's going to be very helpful" (Profile: Senators are Upset ). The administration got caught again when Powell presented a photograph in his highly touted U.N. speech giving support for the U.S. position; the photo alleged to be a terrorist and explosives training center turned out to be a small Kurdish village (Daraghi).

British columnist John Pilger accused the United States and the United Kingdom of using scare tactics in warnings of anthrax and germ warfare attacks as well planting stories linking Iraq with terrorists. "The absurdity of all this is becoming grotesque, and the British public needs to ask urgent questions of its Government," Pilger wrote (Pilger, 2002). He complained of "black propagandists" who repeated disproven accusations "to justify an unprovoked attack on Iraq by linking the regime in Baghdad with alQaeda terrorism...."

A small group of retired CIA officers appealed to colleagues still inside to go public with the Bush administration's skewed claims on Iraq to support its case for war with Iraq. "It's been cooked to a recipe, and the recipe is high policy," complained Ray McGovern, a 27-year CIA veteran who briefed top Reagan administration security officials before retiring in 1990 (Lumpkin).

Former United States Information Agency cultural official Nancy Snow called the Bush administration's propaganda war "the most integrated part of the New War," a game featuring "surround-sound of language and image control." Today propaganda infiltration of the media system is more intense than ever, with religious-overtone words like "crusade" brought into political talk. Once the administration declared a "war" on terrorism, she noted, debate was done (Snow). The administration earmarked \$520 million to focus on "disaffected populations" in the Middle East and South Asia and the establishment of a 24-hour Arabic language satellite news network called Radio Sawa. New York PR woman Charlotte Beers, who made her name by promoting Uncle Ben's Rice, designed a massive State Department pub- 
lic relations program and vowed to reach a "30 percent conversion rate" among Muslims, but after several months and numerous problems, Beers resigned (Snow).

Knightley, author of a book on war reporting, complained that reporting on wars in western media follows 'a depressingly predictable pattern' : stage one, the crisis; stage two, the demonization of the enemy's leader; stage three, the demonization of the enemy as individuals; and stage four, atrocities. Though he focused on the U.S. attack on the Taliban in Afghanistan, his assessment also fits the runup to the attack on Iraq. While politicians talk diplomacy and plan war, he wrote, media tell the public: "We're on the brink of war," or "War is inevitable" (Knightley), until the plaint becomes a self-fulfilling prophecy.

\section{Complaints about Media Coverage}

Complaints about U.S. media coverage range from failure to cover stories to publishing administration propaganda without regard to its truthfulness. Even when a major news organization investigates and publishes important news, other outlets virtually ignore it. During the Bush-Gore presidential campaign, The Boston Globe investigated how Bush avoided going to war - an issue that hounded Bill Clinton throughout his presidency - and discovered that Bush had failed to fulfill obligations to the National Guard, a prized spot he got in 1968, leapfrogging over 500 other men on the list (Robinson, Walter V.) But a search of electronic databases turned up no other newspaper that ran the information. Even before the Bush team made public its plan to remake the Middle East, U.S. media had given Bush a pass on important stories. In summer of 2001, scandal-hungry mainstream media chased any scrap of a story on the missing former aide to Rep.Gary Condit while ignoring Bush's appointment of several Iran-Contra veterans to key posts. "But with a few admirable exceptions, news stories about Elliot Abrams, John Negroponte and Otto Reich have largely relied on past reporting and he-said, she-said soundbites by the usual supporters and critics, rather than in-depth investigations into their complicity in one of the bloodiest scandals of the past 20 years," Terry J. Allen wrote for FAIR. "And their guilt is based not on speculation or gossip, but on hard evidence that they aided torturers and death squads, circumvented Congress and the Constitution, and deceived the American people." The same three Reagan-era officials surfaced again for their role in a coup that ousted Venezuelan president Hugo Chavez briefly and set off a year of instability, the London newspaper, The Observer, published the story (Vulliamy).

The Bush administration set out early in his first year to squelch criticism. The National Writers Union sent a letter listing 10 specific anti-press actions by the administration in September and October, 2001 ("Call for Press Freedom during Times of War"). The list included press secretary Ari Fleischer's Sept. 26,2001 , caution to journalists and to the public that they need to "watch what they say," Rice's conference call with five television network executives in which they agreed not to air video from Osama bin Laden or terrorists and Fleischer's statement that he would probably make a similar request to newspapers. Journalists noted soon after Fleischer's warning to watch what they said that the press secretary's tirade had been scrubbed from the text posted on the White House website and wasn't reposted for several days (Rich). By Sept. 28, 2001, WorkingforChange reported that the White House wasn't "playing nice anymore." Communications staffers warned reporters not only to watch what they say but openly played favorites in setting up interviews and acknowledged it would lie to the public. "The White House has developed a particularly tense, mutually distrustful relationship with members of the news media" (WorkingforChange.com).

The New York Times and major television networks ignored a story broken by the London-based $O b$ server about U.S. spying on U.N. Security Council diplomats. Media-watchdog FAIR also noted that major U.S. media had swallowed administration allegations as if they were fact despite mounting evidence that many claims were bogus (FAIR, "New York Times and Networks"; "A Failure of Skepticism"). Various anti-war groups with websites picked up stories from abroad that American media did 
not print to disseminate to their readers (See, for instance, Take Back the Media, Who Dies and Truthout).

Dissent has triggered angry response from Bush officials and their supporters. The Screen Actors' Guild, fearing McCarthy-era witch hunts, condemned what it called blacklisting in the wake of Sean Penn's difficulties with publisher Rupert Murdoch after Penn's trip to Iraq and Martin Sheen's warnings about his anti-war protests ("Actors Guild").

Anti-war groups have complained that mainstream media ignored them or misrepresented the number of protestors. "Why Did Mainstream News Media Downplay the 100,000+ Antiwar Protestors in D.C. In October?" asked Buzzflash News Analysis. The New York Times, Washington Post and NPR -- which conservatives consistently point to as bastions of the liberal press -- severely underplayed the event or else limited the coverage to inside sections of the newspaper. NPR put the number at "fewer than 10,000," The New York Times reported "thousands" but "fewer people attended than organizers had said they hoped for" (Buzzflash). A public outcry generated a second-day story in The New York Times that conceded the strength of the growing antiwar movement and issued new, more accurate attendance numbers for the march - without calling the story a correction (FAIR).

Todd Gitlin, who studied media inattention to social protestors in the " 60 s and is now a profe ssor, noted that the reasons war dissenters gave for their disagreement got scant attention from the news media. "At the TV networks, there is not even embarrassment about this short-shrifting of dissent and argument in a sound-bite culture" (Gitlin).

\section{Research Methodology}

The venerable Karl W. Deutsch, like many early communication scholars, spent many years parsing out the links between mass media and public life and government. Newspapers could be "an early warning system" since media attention to a conflict area or an enemy country could "harden public opinion to such a degree as eventually to destroy the freedom of choice of the national go vernment concerned" (Deutsch, 1957, p. 202). By measuring the attention allotted to specific interstate conflicts and issues and determining leaders' memory of the news, Deutsch hoped to determine the media messages' cumulative effects.

Hunt developed a straight-forward content analysis methodology based on Deutsch's ideas that showed great power in predicting when presidential administrations made the decision to go to war (1997). Hunt determined that newspaper editorials in elite newspapers telegraphed leaders' plans, not through direct intervention in democratic societies but through the interaction of media and political elites and their similar interests and backgrounds. In the United States, editorials in The New York Times predicted war decisions in a Democratic Party administration, and The Wall Street Journal served the same purpose when a Republican was president. Hunt found that as few as two editorials could indicate when the decision to begin hostilities had been made.

The research question is :

"Do editorials in The Wall Street Journal predict when President Bush would make or made the decision to commence the second phase of his war on terrorism, the "shock and awe" attack on Iraq?"

Operationalizing the action aspect of the question is the most difficult aspect. When did the United States 'go to war" against Iraq? Several bombing raids during the Clinton administration were followed by regular attacks during the Bush presidency. Therefore, the logical choice would be the "shock and awe" phase that began as troops and machinery of war massed on the Iraqi borders by early March, 2003. 
The content analysis included all editorials in the Wall Street Journal from Sept. 12, 2001, through March 12, 2003. All editorials in Lexis-Nexis for the specified months were included in the study as well as editorials published on the newspaper's OpinionJournal online that did not appear in the LexisNexis listing. Identifying editorials was not an issue since both Lexis-Nexis and the online Journal ind icated which items were editorials. ProQuest was used to obtain the editorials by searching on the words "Bush," Hussein" and "Iraq." Hunt found the methodology to be sufficiently robust even when limited to content analysis over short times; for his study of the 1991 U.S.-Iraq war, Hunt analyzed editorials published from Aug. 2, 1990, through Jan., 15, 1991.

Hunt stipulated two main conditions in assessing decision-making to go to war. (1) Efforts to build pubic opinion should precede all wars and (2) the level of opinion-building effort should be commensurate with the level of subsequent interstate conflict (p. 155). He divided editorials into analytical - the "normal" piece that focuses on the actions of the potential adversary rather than the actions of the home nation, written in a conciliatory, cautious tone. An analytical editorial does not propose a violent solution to a problem with another nation. The second type, critical, has a higher level of vitriol, namecalling and harsh words. Critical editorials focus on justifying a unilateral action or threatening some escalation. (Full coding instructions are included in Hunt, pp. 211-213).

Using the Wages of War data set (Singer and Small), Hunt studied pairs of nations, pitting each nation against all others and dividing them into war and no-war groups. Editorials were coded into analytical and critical for each month, logit regression applied, with editorial count as the only independent variable, and a graph created with likelihood of war on the vertical axis and the number of editorials on the base. "Such an analysis provides striking support for hypothesis H1, that wars are preceded by an effort to build pubic support...(T)his chart suggests that wars may be indicated by only two or more critical editorials, rather than the three or more suggested by data set 1 (in which Hunt counted but did not code editorials). In only 2 cases of the 139 cases was war not preceded by two or more critical editorials Iraq-Kuwait and Iran-Uganda. The failures occurred, Hunt wrote, because he had been unable to get the "elite" national newspaper from Iraq and from Uganda (66). In his no-war sample, Hunt found no nation in which two or more critical editorials were written of a potential target nation. Editorials predicting war become clearer as war approaches, Hunt suggested, with the most reliable indications in the month before the onset of war.

Hunt's methodology is well suited to this project because of several unusual aspects of the conflict. President George W. Bush's father, George H. W. Bush, masterminded the 1991-2 Desert Storm war and was the victim of an assassination attempt allegedly by two Iraqis. Some critics cite vengeance as one of the younger Bush's motives for vowing to bring about a "regime change" in Iraq, while others cast his rationale in an economic mode since Iraq has the second-largest oil reserves in the world, second only to Saudi Arabia. The messy evidence presented to justify the war, including several pieces of suspect data, quarreling with longtime allies France and Germany, and offering huge loans or gifts to gain allies, clouds the picture further. Some 250,000-300,000 troops from the U.S., the U.K. and Australia and materiel await the start of war in states surrounding Iraq - a country of about 20 million people -- as Bush threatened to attack. U.N. inspectors supervised destruction of much of Iraq's store of weapons after the 1991 war, and Iraq was ordered by the U.N. to complete the destruction and not rebuild. Also, frequent bombings of the unauthorized "no-fly zones" -- as many as six flights a day during the first months of 2003 - by the United States and United Kingdom served as a "softening up" process that attempted to destroy Iraq's communication systems. As Bush threatened to start his "shock and awe" delivery of thousands of missiles and other munitions in one massive blast to begin the war, Iraq could be likened to a bull in a ring, weakened to the point of exhaustion by the picador, allowing the matador to attack the almost-lifeless bull without fear, possibly a plan to induce Hussein to go into exile rather than face the attackers. 


\section{Results}

Even casual reading of The Wall Street Journal makes clear that the newspaper has been a staunch supporter of Bush and the hawks in his cabinet since his campaign began. After he was placed in the presidency, editorial writers talked to him (in print) as if he were their son, someone they felt like counseling, even chastising, but only in supportive terms.

From Sept. 12 through December, 2001, the Journal published 14 editorials dealing with Iraq; 10 of those were analytical and two of the four critical editorials dealt with the older Bush's failure to remove Hussein (with an implied caution to the younger Bush). The author and two graduate students coded the editorials, with reliability figures of .80 and .85 percentage agreement. Subsequent consultation resulted in agreement on all coding. Interestingly, Journal editorials on Afghanistan as attacks began there pointed toward further conflicts. A Dec. 19, 2001, editorials began: "As Donald Rumsfeld keeps telling us, the war on terror is far from over. But as its initial phase in Afghanistan winds down with notable success, it's a good time to consider what we've learned and how that should inform what comes next."

The ominous tone of the lead continues near the end for the editorial: "This (the U.S.'s hege mony) has obvious implications for the war's next phase, especially action against Iraq." The writer celebrated the likelihood that Bush would have allies in an attack on Iraq but added: "The indispensable new condition would be an American President serious about the job. The signs of Mr. Bush's growing seriousness has even moved the Saudis on the Iraq question; at least now they'd support a U.S.-led coup in Baghdad, if not yet a free election."

In a Sept. 13, 2001, editorial, the writer took a swipe not only at "Bill Clinton's feckless bombing of Osama bin Laden in Afghanistan in 1998" and the senior Bush's failure to take out Hussein. Referring

\begin{tabular}{|l|c|c|c|c|c|c|}
\hline \multirow{2}{*}{} & \multicolumn{2}{|c|}{$2001(14)^{*}$} & \multicolumn{2}{c|}{$2002(45)$} & \multicolumn{2}{c|}{$2003(19)$} \\
\cline { 2 - 7 } & Analytical & Critical & Analytical & Critical & Analytical & Critical \\
\hline Jan & & & 0 & 1 & 0 & 5 \\
\hline March & & & 1 & 0 & 3 & 5 \\
\hline April & & & 0 & 2 & $1 *$ & $5 *$ \\
\hline May & & & 1 & 0 & & \\
\hline June & & & 0 & 0 & & \\
\hline July & & & 1 & 0 & & \\
\hline Aug & & & 1 & 3 & & \\
\hline Sept & 7 & 1 & 7 & 4 & & \\
\hline Oct & 2 & 0 & 2 & 7 & & \\
\hline Nov & 0 & 1 & 1 & 4 & & \\
\hline Dec & 1 & 2 & 3 & 3 & & \\
\hline Total & $10(71.4 \%)$ & 4 & 19 & 26 & 4 & \\
\hline
\end{tabular}

Table 1. Critical Editorials from Sept. 2001 to March 2003

*March 1-12, 2003, only 
to the attacks in New York and Washington, the writer added: "We would not be surprised if this week's atrocity was the work of either Saddam or bin Laden or both." Looking back, it is amazing how strident the Journal was and how determined to bring Hussein into the picture. A Sept. 21, 2001, editorial blamed Secretary of State Colin Powell for advising the senior Bush in 1991 not to oust Hussein and for arguing within the younger Bush circle against such a strike. "Our own view is that the terrorist threat won't vanish until Saddam does," the editorialist wrote.

Table 1 clearly shows that Journal critical editorials escalated dramatically as Bush's decision to when to attack Iraq with "shock and awe" bombings and missile hits neared. (The decision to start with Iraq in remaking the Middle East, with Israel in a favored position, had apparently been made by others even before Bush won his first public office. That he would be so willing to put many of them in high offices and carry out the plan, advised regularly by the Journal, is an interesting if not surprising footnote.) In June 2002, the newspaper published not a single editorial dealing with the search terms, Bush, Iraq or Saddam Hussein. An examination of where the newspaper focused its attention during that period and what other events affecting the drive to Iraq might help explain the absence. By September, the Journal published 11 editorials involving Iraq, Hussein and Bush, of which only four were critical. The September spike stands out in Figure 3, with a more prolonged spike in February into March, 2003.

From that point, the drumbeat continued to grow louder, with nine editorials in October, of which seven were critical. Another lull anticipated the storm of eight editorials in February 2003, of which three that dealt with auxiliary topics - Eastern European nations' support of going to war, for example - were rated analytical.

As is readily seen, the drumbeat for war ebbed and flowed from Sept. 11, 2001, forward, escalating rapidly from August 2002 forward. Immediately after the Sept. terrorist attacks in New York and Washington, the Journal began calling for war against Saddam Hussein. In an editorial Sept. 19, 2001, noted that Bush had nearly universal public support before he started any military action. The next day, the paper warned that "war won't end in Kabul," but targets were limited to "terrorist camps in Syria, Sudan, Libya and Algeria, and perhaps even in parts of Egypt." Then the writer took up the language and tone that the Journal would make ever shriller: "The granddaddy of these countries is Iraq, and - no surprise - reports are swirling that Saddam Hussein was also behind last week's attacks." The editorial said that Israeli military intelligence believed Iraq had helped finance the assault and that Mohamed Atta, team leader of the World Trade Center and Pentagon assaults, "also reportedly met with a senior Iraqi intelligence official in Europe a few months ago."

The words and phrases heard in Bush's speeches - crusade, "just" and "moral" war, "Either you are with us, or you are with the terrorists" - resounded in Journal editorials.

After reading a few of the Journal's editorials, readers become accustomed to certain pairings: "feckless" always went with "Clinton" and Saddam Hussein was never far from "regime change" or "depose" or "thug." The newspaper's name calling extended to Germany and its leaders, France and its leaders and Hans Blix, with less critical words for Kofi Annan. Readers don't have to read the editorials: the paper sums up its main theme in the headline, then follows with an abstract that doesn't mince words. An Oct. 22, 2002, editorial was headlined 'Sadam Ceausescu? Maybe regime change won't require war." An anti-Blix editorial Nov. 23, 2002, proclaimed "Hans Blix's Third Try: Will the chief U.N. inspector agree to another Iraq whitewash?"

If Hunt's thesis successfully predicts when Bush will get to war, the increase in belligerent editorials that began in February would warn "the enemy" to run for the hills. Hunt found that two critical editorials were sufficient to predict "getting to war" and if the number of critical editorials (in this case, 5 in February and 5 in the first 12 days of March) predicts the magnitude of the war, Iraqis seem doomed to suffer the "shock and awe" that Bush has promised. Hunt's more sophisticated mathematical testing of 
the relationship between the variables would undoubtedly yield more elegant results, but in his work, as here, the simple numbers seem sufficient to predict a nation's actions.

\section{Discussion}

It seems clear that President George W. Bush will order the forces on the borders of Iraq to move into the country. With polls in the United States supporting such a move by large percentages and investigative journalism on holiday, he risks little political capital. However, public opinion that is not informed tends to volatility, and majority support can turn into majority opposition quickly. In addition, one of the lessons of the Vietnam is that public opinion responds to bodies of military personnel coming home in caskets as well as to television pictures of innocent victims' suffering. Perhaps shocking pictures will trigger political interest in more Americans, particularly if the economy remains slow. Those who opposed Bush's presidency - a plurality of those who voted, leading to Bush's becoming the first president in American history chosen by the U.S. Supreme Court - could represent a core of continuing protest.

The content analysis as a barometer of war fever produced astonishing results, partly because Wall Street Journal editorial writers don't hold back; they let the venom - and name-calling - flow. The message is clear; the focus and intended belief and actions are unmistakable. As a result, even people with low political or historical knowledge can seize upon buzzwords, jump on the bandwagon and feel that they are taking part in history, particularly if a pollster calls. Is this "the new American way"? Whether this produces a stable, well-functioning democracy is perhaps a question for several additional studies. One study of post-Sept. 11 reactions found that Bush had been able to frame the issues and the language of public discourse in such a way that a majority of Americans have supported him on issues that they link to the Sept. 11 attacks (Huddy et al., 2002). The team studied all major polls since Sept. 11 and found that Americans sense of threat decreased, as did support for government's monitoring their private lives and confidence in the ability of government to stop terrorist attacks; however, the American public's support never wavered for intervention in Afghanistan, President Bush's handling of the campaign against terrorism, and military action against other countries that support terrorism. Readers of the Wall Street Journal would have been right at home; never did the Journal stray from its wholehearted support of the president, even when editorialists chose to chastise his Secretary of State (it was Powell, you see, who argued against deposing Hussein in 1991) or reminding readers that Bush Sr. was too soft on Hus-

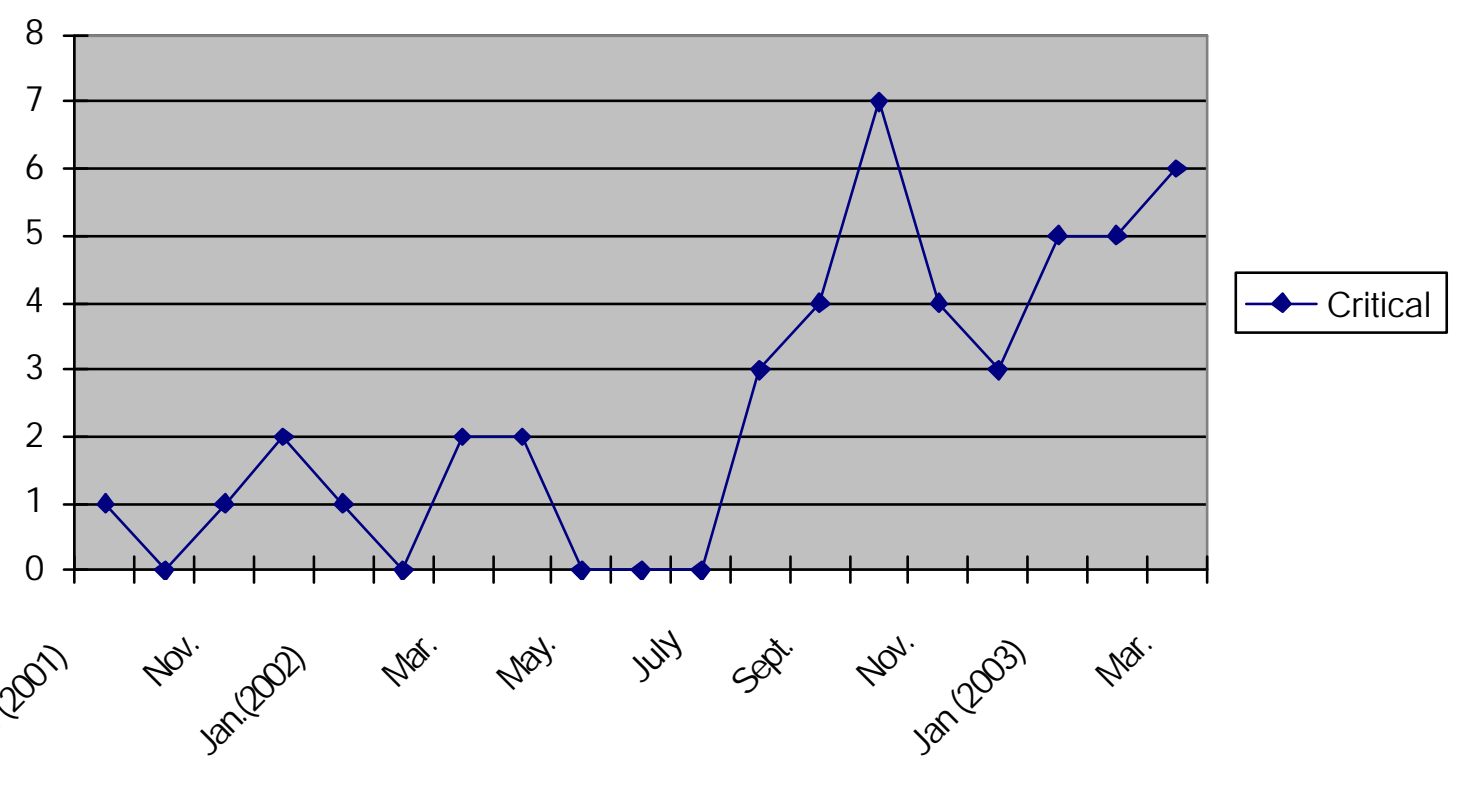

Figure 3: I ine Granh of Critical Editorials 
sein (for the same reason - not taking out Hussein).

This research raises serious questions about the state of the media and the prospects for democracy in the United States that have been raised in other ways by numerous journalists and scholars (Chomsky, 2002, for example). Whether the timidity of contemporary U.S. media is a symptom of overall societal ills that are also reflected in voting patterns, knowledge lacks and other social ills or whether the media are, as some critics would claim, the cause of the problems has long been debated. Norris developed a "virtuous circle" theory to explain her judgment that post-industrial civic disengagement, ignorance of civic affairs, and mistrust of government demand understanding and confrontation of "deep-rooted flaws in systems of representative go vernment" (2000).

While many assessments of media performance in the time of Bush have been dismal, some academics hold out hope. Work by Shah, et al. suggested that the media's revelation of conservative elites' attacks on President Clinton framed the Lewinsky story in such a way as to gain public support (Shah, et al., 2002). Another hopeful message comes from a study by Guo and Moy; the study provided "convincing evidence for news media effects on learning," with newspaper news predicting knowledge and television use predicting interest (1998). While television failed to add to viewers' knowledge as much as newspapers, the authors stressed that the results do not suggest that television is "inherently incapable of enhancing political sophistication. Given the role newspapers were expected to play in the political life of the United States at the time it was founded, a role enshrined in freedom of the press and freedom of expression clauses in the First Amendment, it would seem that greater academic attention might need to be paid to the industry and to television's capability of informing and engaging citizens.

\section{References}

Al-Jazeera journalist held at Guantanamo : Reporters Without Borders urge the US to break its silence (2002, Sept. 20). http://www.rsf.fr/article.php3?id article $=3843$

Allen, Terry J. “Scandal? What Scandal? Bush's Iran-Contra appointees are barely a story” in Extra!, September/October 2001. http://www.fair.org/extra/0109/iran-contra.html

Almond, Gabriel (1950). The American People and Foreign Policy. New York: Harcourt, Brace. Reprinted by Praeger, 1960.

Alterman, Eric (2003, April 7) Stop the Presses: Perle, Interrupted. The Nation. http://www.thenation.com/doc.mhtml?i=20030407\&s=alterman

American Civil Liberties Union (March 10, 2003) "Stop the New Patriot Act." http://www.aclu.org/SafeandFree/SafeandFree.cfm?ID=11904\&c=206\&Type=s

Bailey, Thomas A. (1948). The Main in the Street: The Impact of American Public Opinion on Foreign Policy. New York: Macmillan.

Borger, Julian (2002). Democrat hawk whose ghost guides Bush: Scoop Jackson's body is 20 years in the grave but his spirit goes marching on. The Guardian, 21.

Borzou, Daragahi (2003, Feb. 8). Islamic militants show press the camp Powell called poison site. Associated Press, http://www.rcfp.org/behindthehomefront/docs/ap20030210a.html

Bryce, Robert, and Borger, Julian (2003, March 12). Cheney is Still Paid by Pentagon Contractor: Bush deputy gets up to $\$ 1 \mathrm{~m}$ from firm with Iraq oil deal . http://www.guardian.co.uk/Iraq/Story/0,2763,912515,00.html accessed March 12, 2003.

Campbell, Kim, (Nov. 15, 2001). "For the Scoop, more Americans turn to the Brits," Christian Science Monitor. http://www.csmonitor.com/2001/1115/p17s1-ussc.html accessed January 2003.

Carroll, Joseph (2002, Dec. 27). George W. Bush is 2002's Most Admired Man, No Consensus on Most Admired Woman: Hillary Clinton, Oprah Winfrey, and Laura Bush among most admired women this year. The Gallup Organization. http://www.gallup.com/poll/releases/pr021227.asp?Version=p, accessed December 2002 as subscriber. 
Center for Excellence in Higher Education (2000, Feb. 15). Cuny Students Flunk American History $60 \%$ Would Be Denied U.S. Citizenship; 70\% Would Fail High School Regents Exam. http://www.efpr.org/cehe/cuny history.htm accessed September 2002.

Clymer, Adam (2003, Jan. 3). Government Openness at Issue as Bush Holds On to Records. The New York Times.

Confessore, Nicholas (2002, March 11). Beat the Press: Does the White House have a blacklist? The American Prospect Vol. 13, No. 5.

Cook, Fay Lomax, Barabas, Jason, and Page, Benjamin I. (2002). Invoking Public Opinion: Po licy Elites and Social Security. Public Opinion Quarterly, Vol. 66, 235-264.

Deutsch, Karl K.W. (1957). Mass Communications and the Loss of Freedom in National Decision-making: A Possible Research Apporach to Interstate Conflicts. In Journal of Conflict Resolutions 1, No. 2, 200-211.

Deutsch, Karl K.W. (1966). The Nerves of Government: Models of Political Communication and Control, second edition. New York: Free Press.

Drew, Elizabeth (2002, Dec. 5.)War Games in the Senate. The New York Review of Books.

Editor and Publisher International Yearbook (2003). “Top 100 U.S. \& Top 10 Canadian Sunday Newspapers” accessed January 2003.

Engel, Matthew (2003, Jan. 13). Bushwhacked: With war looming it is no good the American public looking to its newspapers for an independent voice. http://media.guardian.co.uk/Print/0,3858,4581887,00.html accessed January 2003.

Fahey, John (2002, Nov. 21). Students lost at geography: Canadians finished 7th. 89\% of Americans could find their own country, only one in 7 could find Iraq. Montreal Gazette, A16.

Fairness \& Accuracy in Reporting. (2003, March 18). FAIR STUDY: In Iraq Crisis, Networks Are Megaphones for Official Views. http://www.fair.org/reports/iraq-sources.html. Accessed March 18, 2003.

Frum, David (2003). The Right Man: The Surprise Presidency of George W. Bush. New York: Random House.

Gladstone, Brook (2003, March 14). On the Media: Pressing for Answers, National Public Radio, WNYC. http://www.wnyc.org/onthemedia/transcripts 031403 press.html accessed March 2003.

Global Goofs: U.S. Youths Can’t Find Iraq. http://www.cnn.com/2002/EDUCATION/11/20/geography.quiz/.

Graham-Brown, Sarah (2001). "No-Fly Zones: Rhetoric and Real Intentions," http://www.globalpolicy.org/security/issues/iraq/2001/0220nofl.htm, accessed January 2002.

Heldenfels, R.D. (2003, March 18) War won't take over TV for long: Some telecasts will quickly go back to normal. http://www.ohio.com/mld/ohio/entertainment/columnists/rd heldenfels/5418603.htm accessed March 2003.

Holsti, Ole R. (1996) Public Opinion and American Foreign Policy. Ann Arbor: The University of Michigan Press.

Huddy, Leonie, Khatib, Nadia, and Capelos, Theresa (2001). The Polls - Trends: Reactions to the Terrorist Attacks of September 11, 1001. Public Opinion Quarterly, 66, 418-450.

Hunt, W. Ben (1997). Getting to War: Predicting International Conflict with Mass Media IndicatorsI. Ann Arbor: University of Michigan Press.

If he makes it, we're doomed (n.d.). http://www.britishexpat.com/fun/doomed.htm, accessed December 2002.

Jones, Jeffrey M. (2003). Public Support for Iraq Invasion Inches Upward. Gallup Poll, March 14-15, 3003, plus/minus 3 percent margin of error. Sample size 1,007. As found on March 17, 2003 at http://www.gallup.com/poll/releases/pr030317.asp

Journalists Offer Scorecard on Bush and the Media at Forum (2001). http://www.soc.american.edu/main.cfm?pageid=79

Kuttner, Robert (2002). “Teflon Bush,” Boston Globe online, Dec. 18, 2002. www.bostonglobe.com (accessed through Lexis-Nexis).

Lewis, Anthony (2002, Nov. 7) Bush and Iraq: The New York Review of Books.

Lippmann, Walter (1920). Liberty and the News. New York: Harcourt, Brace and Howe.

Lippmann, Walter, and Merz, Charles (1920). "A Test of the News." New Republic, special supplements, 23: 1-42.

Lumpkin, John J. “Ex-CIA Officers Questioning Iraq Data,” Associated Press, March 14, 2003

http://truthout.org/docs_03/031703F.shtml 


\section{Bush, the Media \& the New American Way}

Markel, Lester (1949). Public Opinion and Foreign Policy. New York: Harper and Brothers.

McManus, Doyle (1992, Sept. 11). Questions about Bush's Iran-Contra role resurface. The Los Angeles Times, 3.

Miller, Laura (n.d.). America the Ignorant. http://dir.salon.com/news/feature/2001/09/27/stupidity/index.html, accessed November 2002.

Moore, David W. (2002). Religion \& values: Most religious in predominantly Islamic countries are most negative toward U.S.," April 23, 2002, http://www.gallup.com/poll/tb/religvalue/20020423b.asp (accessed through subscription).

National Council on Economic Education (1999, April 12). Literacy Survey: Results from The Standards in Economics Surve. http://www.ncee.net/cel/results.html\#SUMMARY, accessed November 2002.

National Science Board (n.d.). "Science and Technology: Public Attitudes and Public Understanding Public Interest in and Knowledge of S\&T.http://www.nsf.gov/sbe/srs/seind02/c7/c7s1.htm\#c7s112, accessed February 2003.

National Security Strategy of the United States. http://usgovinfo.about.com/gi/dynamic/offsite.htm?site=http://www.whitehouse.gov/nsc/nss.pdf

Norris, Michelle (2003, March 11). Congress Angry about White House Secrecy.. Profile: Senators Are Upset Over the Bush Administration's Invitation For Bids From Companies to Rebuild Iraq Without their Knowledge or Involvement. All Things Considered, National Public Radio. http://www.npr.org/programs/atc/transcripts/2003/mar/030311.kelemen.html accessed March 11, 2003.

Norris, Pippa (2000). A Virtuous Circle? The impact of political communications in post-industrial demo cracies. Paper for the annual meeting of the Political Studies Association of the UK, London, April 10-13.

Passantino, Jennifer (2002). Americans' Knowledge Of The U.S. Constitution: A Columbia Law Survey. http://www.law.columbia.edu/news/surveys/survey_constitution/, accessed November 2001.

Peterson, Thane (2003). “Deep Inside the Bush White House,” Business Week Online, Feb. 19, 2003. http://www.businessweek.com/bwdaily/dnflash/feb2003/nf20030219 0885 db028.htm

Pilger, John (2002). The myths and propaganda used to 'justify' war against Saddam aim only to distract attention from Bush and Blair's real prize: Iraq's rich reserves of oil. Dec. 3, 2002. http://pilger.carlton.com/print/123925

Pilgrims (The) Magna Carta:Americans Can't Defend a History They Don't Know (Nov. 23, 2001). The Wall Street Journal, http://www.opinionjournal.com/editorial/feature.html?id=95001503

Pool, Ithiel de Sola, Lasswell, Harold D., Lerner, Daniel, et al (1970). The Prestige Press: A Comparaitve Study of Political Symbols. Cambridge, Mass., and London: The M.I.T. Press, 1970. Originally published in four volumes in 1951 and 1952 under the auspices of Leland Stanford Junion University.

Pool, Ithiel de Sola, Lasswell, Harold D., Lerner, Daniel, et al. (1951). "The 'Prestige Paper": A Survey of Their Editorials. Stanford, Calif.: Stanford University Press.

Profile: Senators are upset over the Bush administration's invitation for bids from companies to rebuild Iraq without their knowledge or involvement. http://www.npr.org/programs/atc/transcripts/2003/mar/030311.kelemen.html

Robertson, Lori (2003, Jan/Feb). Poll Crazy, American Journalism Review, 40-45.

Robinson, Walter V. (2000, May 23). 1-Year Gap In Bush's Guard Duty No Record Of Airman At Drills In 1972-73 The Boston Globe.. A1

Rumsfeld remarks: http://abcnews.go.com/wire/World/ap20030123 411.html

Rumsfeld with Hussein, Dec. 20, 1983 http://www.mydd.com/archives/000427.html

Senate Legislative Events Calendar for October 2002, Oct. 4, 2002, SJ 45. http://frist.senate.gov/calendar/2002/october.cfm, accessed continuously.

Shah, Dhavan V., Watts, Mark D., Domke, David, and Fan, David P. (2002). News framing and cueing of issue regimes: Explaining Clinton's public approval in spite of scandal. Public Opinion Quarterly 66 (3), 339-370.

Siebert, Fred S. Freedom of the Press in England, 1476-1776: The Rise and Decline of Government Controls. ChampagneUrbana, University of Illinois, 1952.

Siebert, Fred S., Peterson, Theodore, and Schramm, Wilbur (1956). Four theories of the press: the authoritarian, libertarian, social responsibility, and Soviet communist concepts of what the press should be and do. Urbana: University of Illinois Press. 
Spanish (The) American War (n.d.). National Small Planet Communication.

http://www.smplanet.com/imperialism/remember.html, accessed October 2002.

Speier, Hans (1950). "Historical Development of Public Opinion,” American Journal of Sociolog, LV, 4.

Sperling, Godfrey (2002). "Why the Public is Sticking with Bush," Christian Science Monitor, electronic version, July 30, 2002 edition - http://www.csmonitor.com/2002/0730/p11s01-cogs.html, accessed December 2002.

Strategy, Forces and Resources for a New Century (2000). A Report for the New American Century, September.

Stroebel, Warren P., Landay, Jonathan S., and Walcott, John , "Some in administration have misgivings about Iraq policy," Philadelphia Inquirer, Oct. 7, 2002.

Sydney Morning Herald, "The World Asks: Are Americans Getting the Full Picture?" Nov. 18, 2001

Taiara, Camille T. (2003, March 12) Spoon-feeding the press. The Bush administration's unprecedented war on public information - and how the major news media are going along. The San Fransisco Bay Chronicle. http://foi.missouri.edu/terrorismfoi/spoonfeeding.html accessed March 2003.

Top Democrat requests probe on forged documents on Iraq. The Desert Sun, March 15, 2003. http://www.thedesertsun.com/news/stories/national/1047695639.shtml

Vest, Jason (2001, Nov. 5). Bush's War Hawk. The American Prospect, Vol. 12, Issue 19. http://www.prospect.org/printfriendly/print/V12/19/vest-j.html

Whitaker, Ron (2003). The Decline of TV News Credibility. CyberCollege InterCampus. http://www.cybercollege.com/tvnews.htm Accessed January 2003.

Zaw, Aung (2003, March 18). From Watchdog to Lapdog. The Irrawaddy, http://www.irrawaddy.org/com/, accessed March 2003.

\section{Biography}

Louise F. Montgomery specializes in international mass communication and the interface between go vernment and the mass media. Her work on government and media in Latin America has been published in Journalism and Mass Communication Quarterly and Gazette.

Dr. Montgomery studied at the University of Texas and has taught at the University of Alabama, University of Missouri and University of Arkansas. Her professional journalism experience includes the Dallas Morning News and The Miami Herald.

\section{Appendix 1 \\ Abstracts of All Wall Street Journal Editorials Analyzed}

Author's Note: All editorials published in The Wall Street Journal from Sept. 12, 2002, through March 13, 2003, and all non-duplicated editorials appearing during that time on JournalOnline.com were analyzed to determine whether they were analytical or critical. Anyone unable to access them online may contact the author to receive the entire editorial, the complete abstract or the abbreviated abstract. Full coding instructions may be found in Hunt (1997). What follows are abbreviated descriptions of each editorial taken from the newspaper's own abstracts.

\section{A Terrorist Pearl Harbor}

Wall Street J ournal; New York, N.Y.; Sep 12, 2001;

\section{Abstract:}

The immediate focus of the terrorist drive is of course Israel. But as yesterday's events again show, Israel serves as a proxy for much deeper grievances against the United States and the civilization it repre- 
sents. An undercurrent (or more) of resentment at Western civilization runs through the chanceries and bazaars of the Arab world, as well as a fear of what democracy might mean for the power of local rulers.

\title{
Getting Serious
}

Wall Street J ournal; New York, N.Y.; Sep 13, 2001;

\section{Abstract:}

For fear of hiring rogues, the CIA decided it would only hire Boy Scouts. But the people most likely to inform on terrorists are fellow terrorists. There is always a risk they will behave badly later, and the press will play up that he or she was once paid by the U.S. The bipartisan Bremer panel, whose chairman Paul Bremer elaborates nearby, said this [John Deutsch] rule sent "an unmistakable message to CIA officers in the field that recruiting clandestine sources of terrorist information is encouraged in theory but discouraged in practice." And it led to the sharpest decline in CIA "morale" since the 1970s. For effective anti-terrorism, the CIA needs to be able to dangle enough cash or other incentives to enough bad guys that one of them will talk before Americans die.

\section{The Next Attack}

Wall Street J ournal; New York, N.Y.; Sep 14, 2001

\begin{abstract}
:
The reply is often made that a [Saddam Hussein], say, would never launch a missile attack because the U.S. would respond with massive force. But Saddam wants missiles not merely to strike at the U.S. but also to reduce our ability to act militarily. A President without defenses against missiles would have to think twice before he deployed U.S. forces to the Gulf or to defend some ally. And it is precisely the U.S. ability to project force abroad that is likely to deter the Irans, Iraqs, North Koreas and other states that sponsor and protect Osama bin Laden and other terrorists. In short, missile defense is as much a defense against hijacked airliners as it is against missiles.
\end{abstract}

\section{A New Presidency}

Wall Street J ournal; New York, N.Y.; Sep 19, 2001;

\begin{abstract}
:
George W. Bush now finds himself in far better political circumstances, with nearly universal public support before he undertakes any military action. The public will not soon want to hear from critics who appear to be angling for partisan gain. This means that for the next few months Mr. Bush will have enormous political capital to do whatever he says must be done to help the war effort and buttress national strength. But the lesson of history is that Presidents must spend political capital or they will lose it. And when they spend it and win, they accumulate even more capital.
\end{abstract}

\section{War Aims}

Wall Street J ournal; New York, N.Y.; Sep 20, 2001;

\begin{abstract}
:
Mr. [Bush] has been preparing the country for a large and long military campaign, and by all accounts that's what it is going to take to protect American citizens from attack. In Afghanistan, that almost certainly means the insertion of U.S. ground troops to enter, track down and take bin Laden. This could require airlifting in the 82nd Airborne, presumably by helicopter from Pakistan or from U.S. carriers.
\end{abstract}

\section{Rallying the Country}

Wall Street Journal; New York, N.Y.; Sep 21, 2001 


\title{
Abstract:
}

Secretary of State Colin Powell, for example, is arguing internally not to strike Iraq in any anti-terror campaign, because of its difficulty and its potential to upset other Arab states. But Mr. [George W. Bush] might recall that Mr. Powell also advised his father not to use ground troops to oust Saddam Hussein from Kuwait in 1991. And he was among those who advised George H.W. Bush to end the Gulf War prematurely, leaving Saddam in place to torment this new President Bush.

\section{How We Got Here}

Wall Street J ournal; New York, N.Y.; Sep 24, 2001;

\section{Abstract:}

Soon it emerges that the prime suspect is Ahmed al-Mughassil, leader of the Saudi branch of Hezbollah. Mughassil already is wanted in connection with the November 1995 bombing of a U.S. facility in Riyadh, which killed five Americans.

Saudi cooperation soon ceases, however. Attorney General Janet Reno and FBI

\section{Oust the Taliban}

Wall Street J ournal; New York, N.Y.; Sep 28, 2001;

\begin{abstract}
:
In case there's any genuine U.S. waffling on the Taliban, we'd advise Mr. [Bush] to recall his wellreceived promise to pursue both the terrorists and the states that protect them. To do one without the other is to tell the other states in the region that the U.S. isn't serious.
\end{abstract}

\section{Bin Laden's Clarity}

Wall Street J ournal; New York, N.Y.; Oct 9, 2001;

\begin{abstract}
:
Well, if the Saudi people don't appreciate such distinctions it may be because that the Saudi leaders won't draw them. For starters, Crown Prince Abdullah, brother of King Fahd and de facto ruler of the kingdom, might explain that the 5,000 U.S. soldiers based on Saudi soil were left behind after the Gulf War to protect the Saudi people from Iraq.
\end{abstract}

\section{The Anthrax Source}

Wall Street J ournal; New York, N.Y.; Oct 15, 2001;

\begin{abstract}
:
The anthrax package sent to a Microsoft office in Reno, Nevada, was mailed from Malaysia, another al Qaeda haunt. One of the September 11 hijackers, Khaled Almihdhar, visited Malaysia earlier this year, appearing in a surveillance tape with another suspected associate of bin Laden. The terrorist's followers also met in Kuala Lumpur, the Malaysian capital, in January 2000 as part of the plot to bomb the USS Cole in Yemen later the same year.
\end{abstract}

\section{Our Man in Iraq}

Wall Street J ournal; New York, N.Y.; Nov 5, 2001

\section{Abstract:}

The next error came at the end of the Gulf War, when the CIA estimated that a weakened [Saddam Hussein] would fall within two months. This was one reason President George H.W. Bush decided to end the war prematurely. But with helicopters we let him keep, Saddam crushed the Kurds in the north and 
the Shiites in the South. He finished the job a few years later when he killed most of the former Iraqi military officers whom the CIA had been organizing to take him down. Saddam has proved more adept at infiltrating the CIA's operations than the CIA has at infiltrating his.

\title{
Afghan Lessons
}

Wall Street J ournal; New York, N.Y.; Dec 19, 2001

\begin{abstract}
:
This doesn't mean that the U.S. will never have to deploy large ground forces again. But it does allow for the application of military power with far fewer casualties, which gives a U.S. President many more policy options. In Afghanistan, it allowed the U.S. to topple the Taliban in only two months in a landlocked country half a world away, and with only a hand ful of U.S. casualties so far. It's a remarkable achievement.
\end{abstract}

\section{The Saddam We Know}

Wall Street J ournal; New York, N.Y.; Dec 21, 2001;

\begin{abstract}
:
As the Iraq-Iran war rolls on through the 1980s, perhaps 1.5 million people die on both sides. [Saddam Hussein] himself uses chemical weapons without provocation. The countries agree to a cease fire in 1988. But that same year Saddam uses nerve gas to attack Kurds in the northern Iraqi town of Halabja. Nearly 5,000 men, women and children are killed.
\end{abstract}

\section{Osama on the Run}

Wall Street J ournal; New York, N.Y.; Dec 28, 2001;

\begin{abstract}
:
Conflicting reports yesterday put Osama bin Laden in Afghanistan and Pakistan at the same time, but one place where he was for sure was on alJazeera television, boasting again about what a good terrorist he is. The hunt will no doubt continue, but it's worth considering the latest offering from the all-Osamaall-the-time Qatari station and what it says about where to put the emphasis in the war on terror.
\end{abstract}

\section{State and Saddam}

Wall Street J ournal; New York, N.Y.; Jan 10, 2002

\section{Abstract:}

Back in 1998 bipartisan majorities in Congress passed the Iraq Liberation Act, making it U.S. policy to remove Saddam Hussein from power and appropriating \$97 million for opposition groups like the Iraqi National Congress (INC). But the State Department has often behaved since as if the real U.S. enemy is the Iraqi opposition and not the dictator.

\section{A War Leader}

Wall Street J ournal; New York, N.Y.; Jan 31, 2002

\begin{abstract}
:
It's not as if Mr. [Bush] decided to play it politically safe. Having done well in Afghanistan and standing high in the polls, he might have declared victory and moved onto the domestic agenda. Instead he committed his Administration to fighting what he called the terror "axis of evil," a conscious and powerful echo of World War II. This includes specific states that harbor terrorists as well as the broader terror circle beyond al Qaeda.
\end{abstract}




\title{
Axis of Allies
}

Wall Street J ournal; New York, N.Y.; Feb 26, 2002

\begin{abstract}
:
Also largely unreported was the comment last week of Javier Solana, EU foreign policy chief, who spoke of "overstatements of differences" with Washington. Mr. Solana's remarks were widely taken as a slap in the face of Chris Patten, the EU external affairs commissioner who warned, in widely quoted comments, that Mr. [Bush] was in "unilateralist overdrive."
\end{abstract}

\section{The Inspections Trap}

Wall Street J ournal; New York, N.Y.; Mar 8, 2002

Given his track record, Kofi Annan is the last person who can be trusted to negotiate this kind of inspections regime. If Mr. [Bush] is serious about what even Colin Powell now calls "regime change" in Iraq, the U.S. is going to have to insist on the terms. This is only right, because it is the U.S. -- not France or Russia -- that will be Saddam's target if he ever does acquire the nuclear weapon he covets. Inspections are supposed to trap Saddam, not the U.S.

\section{The 'Mighty Coalition'}

Wall Street J ournal; New York, N.Y.; Mar 13, 2002

\section{Abstract:}

The key issue of Phase Two is what to do about Saddam Hussein. Messrs. [George W. Bush] and [Dick Cheney] have made it clear that the Pentagon has a wanted poster of Saddam posted in its war room charging him with producing weapons of mass destruction.

\section{Quagmire}

Wall Street J ournal; New York, N.Y.; Mar 29, 2002

\begin{abstract}
:
What we do now know is that the results have been precisely the opposite. The violence has only increased, with 46 Israelis dead and more than 350 injured, including 20 dead in Wednesday's horrific Passover Massacre. Israel obliged Mr. [George W. Bush]'s call to pull back from the occupied territories, but the suicide bombers keep coming because Mr. [Arafat] can see that they work.
\end{abstract}

\section{Bush Bends}

Wall Street J ournal; New York, N.Y.; Apr 5, 2002

\begin{abstract}
:
President [Bush] bowed to pressure from Europe, the Arab world and most of the U.S. media yesterday by urging Israel to end its siege against Palestinian terrorists. This strikes us as a mistake, maybe even a large one, though it all might be redeemed if this helps Mr. Bush refocus the war on terror back on Iraq.
\end{abstract}

\section{Saddamonomics}

Wall Street J ournal; New York, N.Y.; Apr 10, 2002

\section{Abstract:}

The world price of oil has been rising, but this is quite apart from anything [Saddam Hussein] is doing. Iraq now exports about 1.5 million barrels of oil a day, or $4 \%$ of world production and perhaps $8 \%$ of U.S. imports. An embargo would hurt the U.S., at least for a while, only if the rest of OPEC agreed to join it. But this is as unlikely as Saddam's making peace with Israel. Saudi Arabia is by far the biggest OPEC player, and it needs every petrodollar it can earn. The Kuwaitis have also rejected an embargo. 


\title{
Arabs and Democracy
}

Wall Street J ournal; New York, N.Y.; Apr 3, 2002

\begin{abstract}
:
The flaw in all this thinking is the one Mr. Sharansky fingered long ago: It depends upon making peace with a leader who has no democratic legitimacy. Under Oslo the Israelis (backed by the U.S.) winked to themselves that they could sub-contract their security out to Mr. [Yasser Arafat].
\end{abstract}

\section{Let Bush Be Bush}

Wall Street Journal; New York, N.Y.; Apr 17, 2002

\begin{abstract}
:
Last weekend alone, the U.S. got caught winking at a failed coup in Venezuela. A news leak targeting Deputy Defense Secretary Paul Wolfowitz seemed intended to undermine Mr. [George W. Bush]'s inspections strategy toward Iraq. And on ABC's "This Week," National Security Adviser Condoleezza Rice admitted that the U.S. isn't sure what it's doing next in the Mideast. "A lot has happened in the last week or so, and we need to assess where we are," she said.
\end{abstract}

\section{The Bush Two-Step}

Wall Street J ournal; New York, N.Y.; Apr 30, 2002

\begin{abstract}
:
On the one hand, Mr. [Bush] says Ariel Sharon is a "man of peace," and that the U.S. will never abandon Israel. He winked for two weeks as the Israeli Prime Minister continued his siege of the West Bank after the President had first said "enough is enough"; he's also implied that Mr. Sharon will be able to repeat his anti- terror sweep if there are more suicide bombers. And he's even tolerated (encouraged?) a Pentagon leak suggesting that planning is proceeding apace for an invasion of Iraq, either later this year or next.
\end{abstract}

\section{Democracy for Palestine}

Wall Street J ournal; New York, N.Y.; May 22, 2002;

\section{Abstract:}

We refer to the unprecedented outpouring of public discontent in Yasser Arafat's Palestinian Authority over the past week. Just a fortnight ago the conventional wisdom was that Israel's lengthy West Bank incursion had only strengthened Mr. Arafat by forcing Palestinians to rally behind their leader; President Bush would be mired in an ever-worsening Israeli-Palestinian crisis as he tried to build a coalition against Iraq.

\section{George and Vlad}

Wall Street J ournal; New York, N.Y.; May 24, 2002

\begin{abstract}
:
For the Russians, that will mean U.S. trade sanctions, especially on steel. The U.S. wants Russia to embrace a free economy and the rule of law, but that's hardly going to sell to Russians if the U.S. market is closed to their goods. We hope Mr. [Vladimir Putin] raises a little hell on the point.

and military structures. One real test of his U.S. friendship will be how long he is willing to tolerate the deployment of U.S. armed forces in the nations along his southern border and north of Afghanistan.
\end{abstract}




\title{
State and the Saudis
}

Wall Street J ournal; New York, N.Y.; Jul 11, 2002;

\begin{abstract}
:
There's also State's apparent acquiescence to the Saudi restrictions on our use of our bases there for offensive military operations, such as the "no-fly zone" in Iraq. U.S. military men and women can protect the Saudis from invasion, but State doesn't object that the Saudis won't let those same U.S. soldiers practice their own religion. When the first President George Bush visited the troops in Saudi Arabia for Thanksgiving during the Gulf War, he was forced to retreat offshore to a ship -- because he was not allowed to say grace on Saudi soil.
\end{abstract}

\section{The Antiwar Party}

Wall Street Journal; New York, N.Y.; Aug 2, 2002

\begin{abstract}
:
A debate in Congress would illuminate all of this and more. Without a vote, the antiwar party will be able to criticize from the bleachers without taking responsibility. There is a serious security argument against such a vote, that it will give [Saddam Hussein] a chance to strike first, perhaps at the U.S. homeland. But a vote in the fall could merely authorize Mr. [Bush] to use force sometime in the future, which would still allow for U.S. surprise.
\end{abstract}

\section{This Is Opposition?}

Wall Street J ournal; New York, N.Y.; Aug 19, 2002

\begin{abstract}
:
Which brings us to Mr. [Brent Scowcroft], who does speak for a point of view worth debating. Honest debate is nothing that advocates of regime change in Iraq, whether President Bush or us, need fear. Indeed, we solicited the Scowcroft article precisely to put on record a view that has a long and honorable tradition, particularly within the Republican Party.
\end{abstract}

\section{Bush's Iraq Resolution}

Wall Street J ournal; New York, N.Y.; Aug 29, 2002

\begin{abstract}
:
Mr. [Dick Cheney] reminds us that inspections are a poor tool against someone like [Saddam Hussein]. In the spring of 1995, inspectors were about to certify that Saddam had shut down his programs aimed at developing chemical and longer-range ballistic missiles -- until Saddam's son-in-law defected. That defection ultimately led inspectors to an Iraqi chicken farm where Saddam was hiding documents about some of his secret weapons programs.
\end{abstract}

\section{Europe and Iraq}

Wall Street J ournal; New York, N.Y.; Aug 30, 2002

\begin{abstract}
:
It has been said -- over and over -- that Europeans won't support a U.S. effort to liberate Iraq from Saddam Hussein. The reality is more politically complicated, and more hopeful for any U.S. plans. President Jacques Chirac did say yesterday that the U.S. should ask for U.N. permission before it ousts Saddam. But it's hard to know if this is a serious objection or pro forma multilateralism.
\end{abstract}

\section{Making the Iraq Case}

Wall Street J ournal; New York, N.Y.; Sep 5, 2002 
Abstract:

He has invited British Prime Minister Tony Blair to Camp David on Saturday, a meeting that follows Mr. Blair's pointed support for the U.S. stance on Iraq yesterday. The Prime Minister echoed Mr.

[Bush]'s point that "doing nothing ... is not an option for the United States" and that much European criticism is "just straightforward anti-Americanism." So much for the argument that the U.S. will have to "go it alone."

\title{
Big Threat, Little Prevention
}

Wall Street Journal; New York, N.Y.; Sep 9, 2002;

\begin{abstract}
:
In particular, Mr. [Bush] now has to decide if he'll accept Secretary of Health and Human Services Tommy Thompson recent recommendation to limit smallpox vaccination to emergency workers. What's odd is that Mr. Thompson is proposing only limited vaccination at the same time he's admitting that smallpox is a clear and present public health threat. His prevention proposal doesn't match his understandable worry, and Vice President Dick Cheney also sounded the same mixed messages yesterday on NBC's "Meet the Press."
\end{abstract}

\section{A Year of Resolve}

Wall Street J ournal; New York, N.Y.; Sep 11, 2002;

\section{Abstract:}

As in the first year of any war, some of the progress is ambiguous or incomplete. Pakistan's military government no longer winks at al Qaeda, but its lack of democratic consent makes it a vulnerable ally. Saudi Arabia's Wahhabi support for terrorism has been exposed as a devil's bargain, but that kingdom has also not yet decided whose side it is on.

\section{Action Will Be Unavoidable'}

Wall Street J ournal; New York, N.Y.; Sep 13, 2002;

\section{Abstract:}

Mr. [Bush] was asking the U.N. to save its own dignity. He pointed to the U.N.'s founding, "after generations of deceitful dictators, broken treaties and squandered lives." He explained at length how [Saddam Hussein] has flouted a litany of Security Council resolutions (16 in all), often citing the conclusions of the U.N.'s own institutions as evidence. And he declared that the U.N. now faces a "difficult and defining moment": "Are Security Council resolutions to be honored and enforced or cast aside without consequence? Will the United Nations serve the purpose of its founding or will it be irrelevant?"

\section{Gore Debates Blair}

Wall Street J ournal; New York, N.Y.; Sep 25, 2002;

\begin{abstract}
:
Where Mr. [Al Gore] sees in those weapons a "threat to the stability of the Persian Gulf," Mr. [Tony Blair] sees a threat to "the stability of the world." While Mr. Gore worries about American "unilateralism," Mr. Blair recognizes that, "Alongside the diplomacy there must be genuine preparedness and planning to take action if diplomacy fails." Where Mr. Gore advises action only "within the framework of international law," Mr. Blair notes that "Unless we face up to the threat . . . we risk undermining the authority of the U.N." While Mr. Gore frets about the Bush doctrine of pre-emptive action, Mr. Blair says, "The one thing I find odd are people who can find the notion of regime change in Iraq somehow distasteful."
\end{abstract}




\title{
The U.N.'s Resolution
}

Wall Street J ournal; New York, N.Y.; Sep 12, 2002;

\begin{abstract}
:
Now, we'll admit to some ambivalence about the first President [Bush]'s decision to request U.N. approval in 1990. We supported the move at the time, but mainly as a way for the U.N. to live up to its original ideals. Left to its own devices, even the Security Council turns into a tower of babble. But with proper leadership -- and today that means U.S. leadership -- the U.N. has done some good. The best examples are the Korean War, when the Soviets were boycotting the U.N. and didn't veto U.S. action to counter the North's invasion of the South, and endorsing force against [Saddam Hussein] in 1990 and
\end{abstract} 1991

\section{Saddam's Oil}

Wall Street J ournal; New York, N.Y.; Sep 16, 2002

\begin{abstract}
:
Optimists argue that even $\$ 30$ oil would not be as devastating to the economy as in years past. The U.S. is less dependent on oil for generating electricity or heating homes. Moreover, if [Saddam Hussein] is unable to attack Kuwait and Saudi Arabia, there isn't much danger of prices going a lot higher as those two countries alone have sufficient reserves to cover any lost output from Iraq. And if Saddam were deposed, and Iraq ruled by more enlightened leaders, that country's oil (potentially as much as three or four million barrels a day) would also go on the world market. Pessimists respond that war is never easy, things will happen we don't expect, and that oil could spike to $\$ 60$, which over several months would be highly damaging for the economy.
\end{abstract}

\section{Putin's Iraq Price}

Wall Street J ournal; New York, N.Y.; Sep 16, 2002

\begin{abstract}
:
Even as the U.N. was still digesting Mr. [Bush]'s speech last Friday, Mr. [Vladimir Putin] appropriated the language of U.S. policy to justify his Georgian meddling. He accuses his southern neighbor of harboring Chechen rebels and others he calls terrorists, and the bold Russian hopes Mr. Bus h will give him a pass in return for approving action against Iraq. This is an offer we hope the U.S. refuses, not least so it can begin better defining just what the new Bush "pre-emption" doctrine means.
\end{abstract}

\section{Disarming Saddam}

Wall Street J ournal; New York, N.Y.; Sep 18, 2002

\section{Abstract:}

Some people, to be sure, will believe anything -- for example, U.N. Secretary General Kofi Annan, who hailed the offer as a great victory. And the Russians, who say [Saddam Hussein]'s word means the Security Council needn't draw up a new resolution after all. And naturally the French, who want not just one new U.N. resolution but two, drawing things out long enough to let Saddam delay any action past the best invasion time of winter. Sophisticates call all of this a "chess game."

\section{Germany Undecides}

Wall Street J ournal; New York, N.Y.; Sep 23, 2002

\section{Abstract:}

That Mr. [Edmund Stoiber] did so well yesterday testifies to how concerned Germans are about the economy. Mr. Stoiber advocated tax cuts for small and medium-sized businesses and labor-market re- 
forms that would allow more part-time and low-wage jobs. But his economic message was often muddied by rhetorical sops to Germany's social consensus. Attacks on immigrants and wavering on Iraq added to the sense that Mr. Stoiber lacked the force and conviction to be a genuine alternative to Mr. [Gerhard Schroeder].

\title{
Wayward Christian Soldiers
}

Wall Street J ournal; New York, N.Y.; Sep 26, 2002;

\section{Abstract:}

This idea seems to be the newest clerical rage now that President Bush has decided to oust Saddam Hussein. The Vatican's foreign minister, Archbishop Jean-Louis Tauran, expressed the Holy See's view that any decision to use force "must come about through a decision taken within the framework of the United Nations." This is the same U.N. that the Catholic Church challenges (rightly, we think) when it pushes for population control and a world-wide right to abortion.

\section{The Democrats and War}

Wall Street J ournal; New York, N.Y.; Sep 30, 2002;

\begin{abstract}
:
Mr. [Al Gore] once rejected this kind of thinking, but in his speech last week he embraced it by noting that the U.S. has taken the world's goodwill after September 11 "and converted it into anger and apprehension aimed much more at the United States than at the terrorist network." Mr. Gore also scored Mr. [George W. Bush] for an "attack on fundamental Constitutional rights" and for a security strategy "glorifying the notion of dominance." Most remarkably, he none too subtly compared Mr. Bush's strategy of pre-emption to the Soviet invasion of Afghanistan in 1979. The Gore Democrats are now anti-anti[Saddam Hussein].
\end{abstract}

\section{The Iraq Coalition Coalesces}

Wall Street J ournal; New York, N.Y.; Oct 4, 2002;

\section{Abstract:}

The support by the Democratic leader means that the Iraq resolution will soon pass the House overwhelmingly. Mr. [George W. Bush] was obliged to make a few concessions -- in demands to consult Congress and a rhetorical bow to multilateralism. But the final product is a clear and forceful endorsement of executive authority to disarm the Iraqi dictator. The language authorizes Mr. Bush to use military force "as he determines to be necessary," both to defend the U.S. against Iraq and "enforce all relevant" U.N. resolutions against Iraq.

\section{How to Liberate Iraq}

Wall Street J ournal; New York, N.Y.; Oct 8, 2002;

\section{Abstract:}

The big point here isn't that the U.S. should be anointing any specific [Saddam Hussein] successor. The idea is that the war will be easier to win, and a post-Saddam Iraq easier to rebuild, if the war itself is seen less as a U.S. invasion than as American help for Iraqis who want to retake their own country.

\section{A United Iraq Front}

Wall Street J ournal; New York, N.Y.; Oct 11, 2002;

\footnotetext{
Abstract:

President Bush's policy to disarm Saddam Hussein picked up 296 wingmen yesterday, with the House
} 
vote approving his request to use military force. The size of the majority -- only 133 voted no -- shows a national consensus to liberate Iraq that might impress even the United Nations Security Council, if not Saddam and some American editorial writers.

\title{
Jimmy Carter's Nobel Intentions
}

Wall Street J ournal; New York, N.Y.; Oct 14, 2002;

\begin{abstract}
:
[Leonid Brezhnev] did not turn his cheek in return. He repaid a falling U.S. defense budget by undertaking a huge military buildup, notably in nuclear missiles. The Soviets bankrolled proxies who extended Marxist rule in Angola, Nicaragua, Afghanistan and nearly in El Salvador. When Islamic radicals threatened the Shah of Iran, a U.S. ally, Mr. [Jimmy Carter] sent indifferent signals and the Shah fell. Soon those same radicals took American diplomats hostage, holding them for 444 days until the very day $\mathrm{Mr}$. Carter left office.
\end{abstract}

\section{A Remarkable Iraq Vote}

Wall Street J ournal; New York, N.Y.; Oct 14, 2002

\begin{abstract}
:
Even more notable was the fact that every Democrat contemplating a run for President, in 2004 or 2008, voted with Mr. [Bush]. Joe Lieberman and Joe Biden have long noted Saddam Hussein's threat, and Hillary Rodham Clinton understands sentiment in New York. But when even John Kerry votes yes, after months of pounding the Bush policy, you know there is a national consensus in favor of confronting Saddam. The odd-candidate out here now is Al Gore, whose anti-anti-
\end{abstract}

\section{Pyongyang's Nuclear Blackmail}

Wall Street J ournal; New York, N.Y.; Oct 18, 2002;

\section{Abstract:}

Then the U.S. can begin to construct a new policy of pressure and containment aimed at changing the rogue regime. Now, let's be clear we aren't suggesting the U.S. go to war; the showdown with Iraq is a higher priority and will itself be instructive to the North. Any scary rhetoric about war, which we expect to hear a lot of, will come from the left and is designed to force the U.S. back toward the Clinton appeasement.

\section{Saddam Ceausescu?}

Wall Street J ournal; New York, N.Y.; Oct 22, 2002

\section{Abstract:}

No doubt [Saddam Hussein] intends this as one more bizarre ploy. A friend of ours suggests that the dictator is engaging in a tradition that dates back to the caliphs, who would release everyone from jail every so often to ensure their popularity. The prisoners will enjoy their freedom for a while, and Saddam's secret police will watch their movements and meetings before rounding them up again.

\section{A French-Russian Veto?}

Wall Street J ournal; New York, N.Y.; Oct 23, 2002;

\section{Abstract:}

We understand the uses of diplomacy, but enough is enough. It's been five weeks since Mr. [Bush] asked the U.N. to act, time is running out on the prime winter season for military action in Iraq, and sooner or later Mr. Bush has an obligation to end this pas de Chirac and call the French and Russian 
Bush, the Media \& the New American Way

bluff. The U.S. should put a blunt, forceful declaration in front of the Security Council, and see if its members really want to veto it.

\title{
Iraq and al Qaeda
}

Wall Street J ournal; New York, N.Y.; Oct 25, 2002;

Abstract:

Is President Bush going to war with Iraq based on a false premise, or worse, a lie? That's quite a charge, yet it's the gravamen of what looks like an orchestrated campaign to suggest that it's crazy to believe that Saddam Hussein would ever join arms with al Qaeda.

\section{Mr. Bush's U.N. Mandate}

Wall Street J ournal; New York, N.Y.; Nov 11, 2002;

\section{Abstract:}

The axis of accommodation (France, Russia, the State Department) is chortling that it has forced Mr. Bush to alter his policy from "regime change" in Iraq to mere disarmament. But if disarmament is at all serious, it will be tantamount to regime change. [Saddam Hussein] governs by terror and the destruction of his terror machinery will be an enormous humiliation. The earlier U.N. resolutions that have now been reinforced also include a demand that Saddam stop oppressing his own people. We doubt, given Saddam's past, that he will be able to tolerate this kind of intrusive foreign interference and survive. He probably can't therefore agree to the U.N.'s terms.

\section{State's Alternative Iraq Policy}

Wall Street J ournal; New York, N.Y.; Nov 13, 2002;

\begin{abstract}
:
One unhappy irony here is that State is undermining precisely those opponents of [Saddam] who most share our values and want to turn Iraq in a modern, pro-Western direction. Another is that in the Bush Administration it is the Pentagon that seems to care most about building a pluralistic Iraq. State's Near East bureau behaves as if it wouldn't mind another Baath Party thug.
\end{abstract}

\section{Kofi's Patience}

Wall Street J ournal; New York, N.Y.; Nov 15, 2002;

\begin{abstract}
:
Mr. [Kofi Annan] is nothing if not patient, at least with [Saddam Hussein]. Throughout the 1990s Mr. Annan helped the dictator water down the U.N. inspections regime and ignore 16 different U.N. resolutions. More recently, he has publicly begged Mr. [Bush] to go through the U.N. Security Council before moving against Iraq. Yet now that the President has obliged him -- and succeeded in getting a compromise resolution through -- Mr. Annan is worried that Mr. Bush might actually enforce its terms.
\end{abstract}

\section{Hans Blix's Third Try}

Wall Street J ournal; New York, N.Y.; Nov 22, 2002;

\begin{abstract}
:
All of which explains why Mr. [Hans Blix] is the man Iraq has all along wanted to lead any renewed U.N. inspections team. [Saddam Hussein]'s minions insisted on Mr. Blix over Rolf Ekeus, who also had previous experience in Iraq but was much more tough-minded. The U.N. hired Mr. Blix.
\end{abstract}




\title{
Aiming to Please, Berlin Offers U.S. Some Iraq Support
}

Wall Street J ournal; New York, N.Y.; Nov 29, 2002;

\begin{abstract}
:
German Chancellor Gerhard Schroeder said Berlin would grant U.S. military forces unrestricted rights to fly over Germany and to use U.S. bases on German soil to support military action in Iraq. But Mr. Schroeder stood firm on his refusal to provide German troops.
\end{abstract}

\section{Dance of Saddam's Seven Veils}

Wall Street Journal; New York, N.Y.; Dec 6, 2002;

\begin{abstract}
:
It's always possible the inspectors will get a break and stumble onto something, much as inspectors got lucky with defections in the 1990s before [Saddam Hussein] threw them out. But Saddam will always win a game of inspect and pretend on his home turf. In the meantime, the world is left to live with the knowledge that, as the British report also notes, Iraq can get weapons of mass destruction ready for use within 45 minutes of Saddam's order.
\end{abstract}

\section{The Trouble With Amnesty}

A "human rights" group suddenly wants to keep Iraqis oppressed.

Journal Online Sunday, December 8, 2002 12:01 a.m. EST

The next time Amnesty International comes trying to sell you a candle this Christmas tell the volunteer you know exactly where it should be displayed--in the sands of a free Iraq, one this organization suddenly seems unwilling to see materialize. The British government has released a detailed dossier showing the horrors Saddam Hussein has inflicted on Iraqis, but Amnesty is now fretting about a war that would end these abuses.

\section{Iran's Popular Revulsion}

Wall Street J ournal; New York, N.Y.; Dec 9, 2002;

Geographic Names: Iran

\section{Abstract:}

If Iran's head is dominated by the theocrats, its heart seems to favor freedom. The government's own pollsters asked Iranians recently whether they wanted dialogue with the U.S., and more than 70\% said yes. In a real democracy that would set off a debate and possibly a change of policy. In Iran, it got the pollsters arrested. Their trial on a long list of charges, including conducting "flawed" opinion polls, began last week.

\section{Scud Seizure}

Wall Street J ournal; New York, N.Y.; Dec 12, 2002;

\section{Abstract:}

He means that since 9/11 Yemen has been cooperating with the U.S. in the war on terror. U.S. Special Forces are in Yemen training soldiers, and last month Yemen gave its approval to a U.S. airstrike in which an unmanned Predator aircraft fired Hellfire missiles that killed six al Qaeda operatives, including one big fish.

White House spokesman Ari Fleischer was hardly clarifying when he said yesterday that the U.S. "had no choice but to obey international law." Does that mean that if the Scuds were headed for Iraq or Libya 
we would also return them? If the Bush Doctrine of pre-emption means anything, the U.S. should have the right to confiscate weapons sold by, and headed for, sponsors of terror.

\title{
Saddam's Burden of Proof
}

Wall Street J ournal; New York, N.Y.; Dec 19, 2002;

\begin{abstract}
:
Reports indicate that the declaration fails to account for what happened to [Saddam Hussein]'s chemical and biological weapons programs since inspectors left in 1998, as well as his nuclear program. Issues unresolved as of 1998 include the fate of: 360 tons of chemical weapons (including 1.5 tons of VX nerve agent); 3,000 tons of precursor chemicals (300 tons of which are unique to the production of VX); 30,000 special munitions for delivering chemical and biological weapons; and growth media for the production of biological weapons (enough to make more than three times the 8,500 liters of anthrax spores that Iraq admits to having manufactured).
\end{abstract}

\section{Our Man in Caracas; Not}

Wall Street J ournal; New York, N.Y.; Dec 18, 2002;

\begin{abstract}
:
Mr. [Otto Reich], as it happens, is a former U.S. Ambassador to Venezuela who knows all of the local players. But he's sitting on the sidelines now because his Presidential recess appointment expired when Congress went home in November. President [Bush] had to settle for the recess term after Mr. [Chris Dodd] refused even to grant Mr. Reich a nomination hearing.
\end{abstract}

\section{Flag Wavers on Campus}

Wall Street J ournal; New York, N.Y.; Dec 20, 2002;

John Kerry will not be pleased to learn that nearly $70 \%$ also said they supported multilateral action against Iraq if the inspections failed. Support drops to $18 \%$ if the U.S. goes in without United Nations backing, though that figure largely mirrors the broader U.S. public.

\section{To Pyongyang Via Baghdad}

Wall Street Journal; New York, N.Y.; Jan 13, 2003

\begin{abstract}
:
Warren Christopher, the Clinton Secretary of State who presided over the 1994 Agreed Framework now shown to be a failure, suggests the U.S. should change its "priorities" from Baghdad to Pyongyang. What does he want, a "pre-emptive" strike? Maybe cruise missiles fired from a thousand miles away at a few North Korean tents? That sure worked well against Osama bin Laden (and there weren't 37,000 U.S. troops just across the border from Afghanistan as a potential target of retaliation).
\end{abstract}

\section{Iraq for Iraqis}

Wall Street J ournal; New York, N.Y.; Jan 22, 2003

\begin{abstract}
:
What concerns us now are reports of heavy-handedness in planning for the transition to a post-[Saddam] Iraq. Opposition leaders complained that Washington tried to call all the shots at their big December meeting in London. Some even threatened a boycott. But the meeting turned out to be a success in any event. The exiles planned a conference for this month in Kurdish-controlled Northern Iraq and the U.S. said it would send a delegation.
\end{abstract}




\title{
If Saddam Survives
}

Wall Street J ournal; New York, N.Y.; Jan 27, 2003

\begin{abstract}
:
Yes, U.N. inspectors might still be searching the Iraqi countryside for a "smoking gun," but everyone will understand that [Saddam Hussein] stood down a U.S. President. America's armed forces couldn't stay massed in the Mideast forever, and so the mobilization of January 2003 is reversed. Far from a coup against Saddam, the dictator consolidates his power with one more purge of his officer corps. His spies assassinate key members of the Iraqi opposition in the Kurdish areas of northern Iraq.
\end{abstract}

\section{A Large Presidency}

Wall Street J ournal; New York, N.Y.; Jan 30, 2003

\begin{abstract}
:
On Iraq, Mr. Bush seethed with determination, making clear he is intent on deposing Saddam Hussein with or without U.N. -- or Democratic Party -- help. He spelled out the Iraqi threat at some length, providing details about Iraq's illegal arms and the extent to which it has gone to conceal its biological, chemical and nuclear programs. He stopped short of a declaration of war, but anyone who observed the look in his eyes knew he meant it when he said this is Saddam's "final chance" and that some "crucial hours" may lie ahead.
\end{abstract}

\section{Our European Allies}

Wall Street J ournal; New York, N.Y.; Jan 30, 2003

\begin{abstract}
:
Mr. [Bush] spelled out that threat in greater detail in his State of the Union address, drawing on British intelligence that has discovered clear links between Saddam Hussein and al Qaeda. Secretary of State Colin Powell is expected to elaborate on those links at the United Nations next week. Given the vast amounts of previously established chemical and biological poisons that are still unaccounted for in Iraq, it doesn't require much effort to imagine the unspeakable havoc such weapons could produce in a major European or American population center. Mr. Bush made this danger a central message of his address and clearly that concern is shared by Europe's clear-eyed leadership
\end{abstract}

\section{The Op-Ed Alliance}

Wall Street J ournal; New York, N.Y.; Feb 3, 2003

\section{Abstract:}

The notion that France and Germany speak for all of Europe is especially absurd, akin to assuming that New York City and Washington, D.C., speak for all of America. Down in the polls, German leader Gerhard Schroeder barely speaks for a majority in his own country.

\section{Powell's Smoking Gun}

Wall Street Journal; New York, N.Y.; Feb 6, 2003;

\begin{abstract}
:
Mr. [Colin Powell] saved his evidence on Iraq's links to al Qaeda until last, but they were certainly worrisome. Al Qaeda and Iraqi agents met many times in the 1990s, he said, and recent cooperation centers around Abu Mussab al-Zarqawi, who operates out of a camp in northern Iraq but has visited Baghdad extensively in recent months for medical treatment. Detainees say he is linked to the al Qaeda cells recently rounded up while plotting poison and bombing attacks in Europe.
\end{abstract}




\title{
New Europe's Vision
}

Wall Street J ournal; New York, N.Y.; Feb 6, 2003

\begin{abstract}
:
While the prospect of war is inevitably sobering, the number of countries pledging their support for a confrontation with Saddam Hussein's regime grows by the day. America's European allies are leading the way. Eight European countries last week backed the Bush Administration in a statement to this newspaper. Ten more -- Albania, Bulgaria, Croatia, Estonia, Latvia, Lithuania, Macedonia, Romania, Slovakia and Slovenia -- made a similar commitment yesterday.
\end{abstract}

\section{Saddam and the Next 9/11}

Wall Street J ournal; New York, N.Y.; Feb 14, 2003

\begin{abstract}
:
America is on orange alert, Osama bin Laden is issuing new threats, and already the opponents of military action against Iraq are preparing to blame the next terror attack on U.S. policy. By threatening Iraq, which has nothing to do with al Qaeda, the U.S. is said to be inviting Saddam Hussein to become another bin Laden.
\end{abstract}

\section{Dick Cheney Was Right}

Wall Street J ournal; New York, N.Y.; Feb 18, 2003

\begin{abstract}
:
President Bush challenged the U.N. to honor its own charter once again, doing everything that Kofi Annan and Jacques Chirac requested and siding with the advice of Tony Blair and Colin Powell that the U.N.'s imprimatur would make disarming Saddam Hussein that much easier. The U.N. Security Council went along in repeating its many disarmament demands, but now that it is time to enforce them it is heading for cover in the French countryside. The U.N. is itself proving that Dick Cheney and Donald Rumsfeld were right in their debate with Mr. Powell over the utility of U.N. inspections.
\end{abstract}

\section{The Turkish Bazaar}

Wall Street J ournal; New York, N.Y.; Feb 21, 2003

\section{Abstract:}

That stalwart commitment is now in question, as the Turks dicker with President [George W. Bush] over how much they'll help the U.S.-led war effort. Unlike the French, the Turks really matter. Turkish bases would give U.S. forces a northern invasion route into Iraq, as well as a model Muslim ally. Their objections at this late date are slowing war momentum and giving [Saddam] false hope he can survive in power.

\section{Holbrooke's Iraq Warning}

Wall Street J ournal; New York, N.Y.; Feb 25, 2003

\begin{abstract}
:
While Mr. [Richard Holbrooke] acknowledges this new resolution has been submitted to provide political cover for British Prime Minister Tony Blair, "something akin to a train wreck is now approaching." A rejection "would leave the clear impression than any military action that follows is in violation of the Security Council's will, rather than being derived logically from the long trail of Iraqi defiance." Whatever Mr. Holbrooke's motives for taking a hard line now -- he was one of those who advocated going to the U.N. for Resolution 1441 in the first place -- this is hard to dispute
\end{abstract}




\title{
The Iraq Coalition Coalesces
}

Wall Street J ournal; New York, N.Y.; Feb 28, 2003;

\begin{abstract}
:
President Bush answered one more objection to his Iraq policy this week, sketching his postwar vision for a more democratic, stable Middle East. Meanwhile, from Britain to Turkey, and even in surprising corners of Paris, the alliance to oust Saddam Hussein is showing signs of coming together.
\end{abstract}

\section{Philippine Flip-Flop}

Wall Street J ournal; New York, N.Y.; Mar 4, 2003;

\begin{abstract}
:
It's too bad Manila doesn't practice what it preaches. President Gloria Macapagal Arroyo has instead just reneged on an agreement with Washington to deploy U.S. troops to help chase down the al Qaeda-linked Abu Sayyaf terrorist group in the southern Philippines. The agreement is unconstitutional, she now says -- not explaining why the Philippine constitution didn't stop her from agreeing in the first place. Other Filipino politicians say a legal agreement could easily have been worked out had the president kept her nerve.
\end{abstract}

\section{Now They Tell Us}

Wall Street J ournal; New York, N.Y.; Mar 10, 2003

\begin{abstract}
:
There have been a couple of exceptions, notably Texas Representative Martin Frost last week, but the strategy of Democratic leaders is unmistakable. House Minority Leader Nancy Pelosi made Iraq the subject of her first major foreign-policy address on Friday, a critique that could have been written in Paris. Tom Daschle is in full antiwar mode, and Ted Kennedy is assailing the President on every TV show that will have him. These Democrats have every Constitutional right to do this, but Americans have a right in turn to ask: Why now?
\end{abstract}

\section{Bush in Lilliput}

Wall Street Journal; New York, N.Y.; Mar 12, 2003

\begin{abstract}
:
The Mexican and Chilean fandango is especially insulting given the preferential treatment their exports receive to the U.S. market. Maybe we should transfer to Bulgaria -- which is supporting us sans bribery - the trade benefits that these two nations apparently take for granted. These columns have long tried sympathetically to explain Mexican realities to our readers, but President Vicente Fox's U.N. war straddle will cost his country years of U.S. public goodwill.
\end{abstract}

